\title{
The effect of unconventional fiscal policy on consumption expenditure
}

by Francesco D'Acunto, Daniel Hoang and Michael Weber

No. 94 | OCTOBER 2016

\section{WORKING PAPER SERIES IN ECONOMICS}

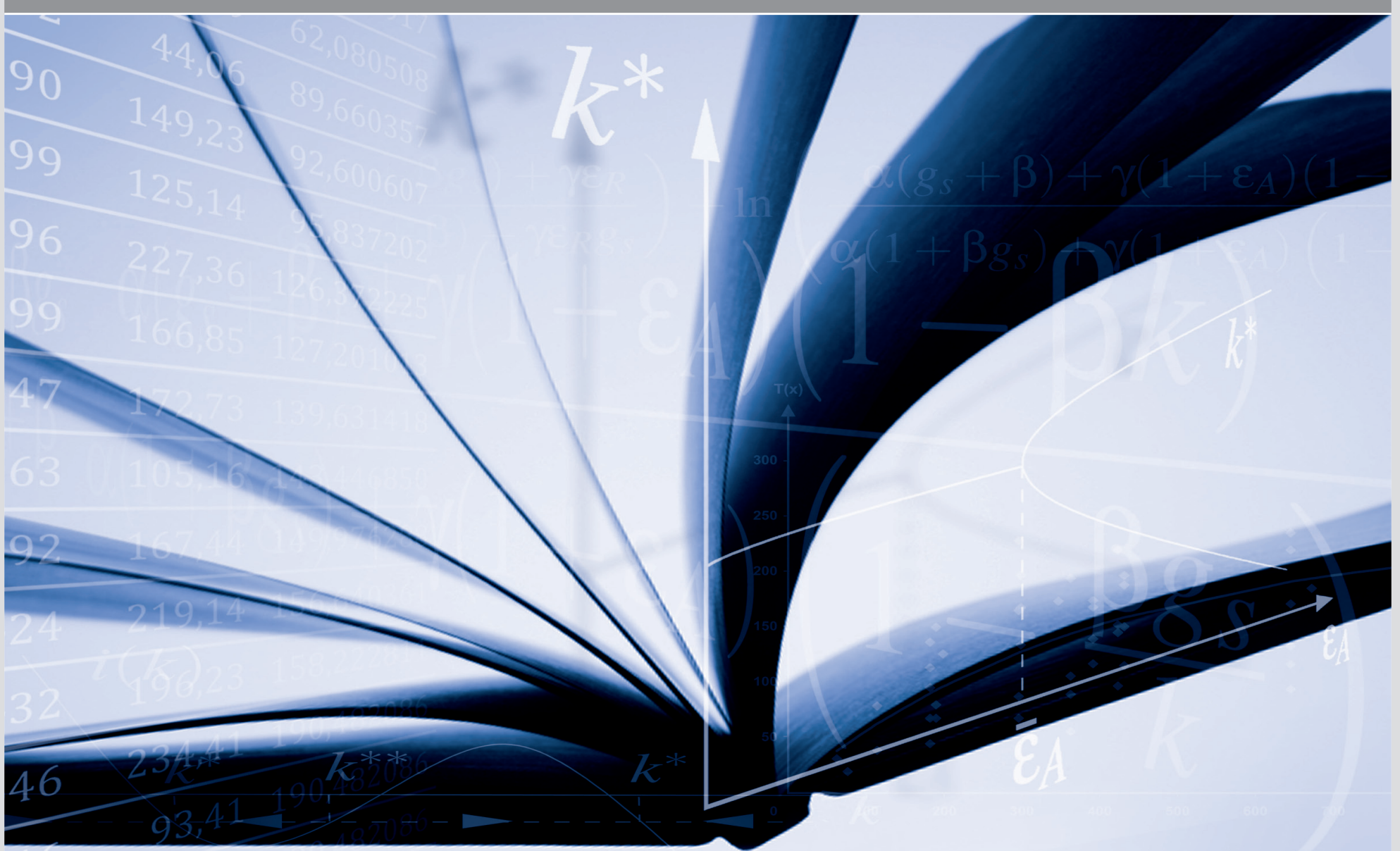




\section{Impressum}

Karlsruher Institut für Technologie (KIT)

Fakultät für Wirtschaftswissenschaften

Institut für Volkswirtschaftslehre (ECON)

Schlossbezirk 12

76131 Karlsruhe

KIT - Die Forschungsuniversität in der Helmholtz-Gemeinschaft

Working Paper Series in Economics

No. 94, October 2016

ISSN 2190-9806

econpapers.wiwi.kit.edu 


\title{
The Effect of Unconventional Fiscal Policy on Consumption Expenditure*
}

\author{
Francesco D’Acunto, ${ }^{\dagger}$ Daniel Hoang, ${ }^{\ddagger}$ and Michael Weber ${ }^{\S}$
}

This version: August 2016

\begin{abstract}
Unconventional fiscal policy uses announcements of future increases in consumption taxes to generate inflation expectations and accelerate consumption expenditure. It is budget neutral and time consistent. We exploit a unique natural experiment for an empirical test of the effectiveness of unconventional fiscal policy. To comply with European Union law, the German government announced in November 2005 an unexpected 3-percentage-point increase in value-added tax (VAT), effective in 2007. The shock increased households' inflation expectations during 2006 and actual inflation in 2007. Germans' willingness to purchase durables increased by $34 \%$ after the shock, compared to before and to matched households in other European countries not exposed to the VAT shock. Income, wealth effects, or intratemporal substitution cannot explain these results.
\end{abstract}

JEL classification: D12, D84, D91, E21, E31, E32, E52, E65

\section{Keywords: Zero-Lower Bound, Fiscal and Monetary Policy, Durable Consumption, Survey Data, Household Consumption .}

*This research was conducted with restricted access to Gesellschaft für Konsumforschung (GfK) data. The views expressed here are those of the authors and do not necessarily reflect the views of GfK. We thank the project coordinator at GfK, Rolf Buerkl, for help with the data and insightful comments. We also thank Rudi Bachmann, David Berger, Carola Binder, Jeff Campbell, Robert Chirinko, John Cochrane, George Constantinides, Giancarlo Corsetti, Dimitris Georgarakos, Austan Golsbee, Yuriy Gorodnichenko, Gary Gorton, Refet Guerkaynak, Anne Hannusch, Erik Hurst, Greg Kaplan, Emi Nakamura, Brent Neiman, Andy Neuhierl, Ali Ozdagli, Jonathan Parker, Luboš Pástor, Christian Speck, Amir Suf, Martin Ruckes, Andrea Tambalotti, Giorgio Topa, Joe Vavra, Johannes Wieland, Mike Woodford, Basit Zafar, and seminar participants at the AEA 2016, Atlanta Fed, Banque de France, Bank of Italy, UC Berkeley, Bilkent University, Bocconi, Bundesbank, Bundesbank PHF Workshop, Boston Fed, Cambridge, Chicago, the Chicago Junior Macro and Finance Meetings, 2015 CITE, the Cleveland Fed Conference, ECB International Research Forum on Monetary Policy, EEA 2015, EIEF, Federal Reserve Board, $8^{\text {th }}$ joint French Macro Workshop, the $5^{\text {th }}$ meeting of the Macro-Finance Society, 2015 Ifo Conference on Macroeconomics and Survey Data, NBER ME 2015, New York Fed Conference on Subjective Expectations, 2015 RBA Quantitative Macro Workshop, SED 2015, and Yale for valuable comments. Weber gratefully acknowledges financial support from the University of Chicago, the Neubauer Family Foundation, and the Fama-Miller Center.

${ }^{\dagger}$ Haas School of Business, University of California at Berkeley, Berkeley, CA, USA. e-Mail: francesco_dacunto@haas.berkeley.edu

${ }^{\ddagger}$ Department for Finance and Banking, Karlsruhe Institute of Technology, Karlsruhe, B-W, Germany. e-Mail: daniel.hoang@kit.edu.

$\S$ Booth School of Business, University of Chicago, Chicago, IL, USA. Corresponding author. e-Mail: michael.weber@chicagobooth.edu. 


\section{Introduction}

Governments around the world struggle to stimulate the economy. Large stocks of sovereign debt limit the scope of fiscal stimulus, whereas the zero lower bound on nominal interest rates and inflated central bank balance sheets constrain conventional and unconventional monetary policy. Macroeconomists have recently proposed unconventional fiscal policy measures to stimulate demand by changing intertemporal prices. Unconventional fiscal policy differs from fiscal stimulus or tax rebates because it does not rely on income effects, is time consistent, and is budget neutral.

Shapiro (1991), Feldstein (2002), and Hall (2011) propose pre-announced increases in value-added tax (VAT) to generate consumer price inflation and stimulate spending via intertemporal substitution without increasing the federal budget deficit. ${ }^{1}$ Correia, Farhi, Nicolini, and Teles (2013) formalize these ideas in a framework with a binding zero lower bound on nominal interest rates. An increasing path of consumption taxes and a decreasing path of income taxes generates inflation expectations, negative real interest rates, and stimulates consumption but does not distort the production decisions of firms. ${ }^{2}$ They find these policies can fully offset the zero lower bound constraint without relying on inefficient commitments on low future interest rates or wasteful government spending. VAT-change announcements are also a salient policy measure to generate inflation expectations. Because of these appealing features of unconventional fiscal policy compared to other fiscal policy or unconventional monetary policy measures, testing for its effectiveness is important.

This paper proposes an empirical test for the effect of unconventional fiscal policy on households' willingness to purchase durable goods. The ideal experiment would consist of an exogenous announcement of higher future consumption taxes and a cut in income taxes. We exploit a natural experiment in Germany that is close to such an ideal experiment. In November 2005, the newly formed German government unexpectedly announced a 3-percentage-point increase in VAT, effective in January 2007. Two features make this announcement uniquely suited to test for the effect of unconventional fiscal policy compared to other changes in VAT. First, the European Union (EU) imposed the announcement on the German administration to avoid an infringement procedure for

\footnotetext{
${ }^{1}$ Feldstein (2002): "This [VAT] tax-induced inflation would give households an incentive to spend sooner rather than waiting until prices are substantially higher."

${ }^{2}$ Eggertsson and Woodford (2004) discuss similar ideas in a Ramsey taxation model.
} 
the breach of the Maastricht Treaty. The VAT increase was therefore unexpected and unrelated to prospective future economic conditions, and qualifies as an exogenous tax change due to inherited fiscal deficits in the taxonomy of Romer and Romer (2010). ${ }^{3}$ Second, Germany had no monetary sovereignty as a member of the European Monetary Union. The European Central Bank explicitly excluded any increase in nominal interest rates to counteract the price pressure from a higher VAT in Germany. ${ }^{4}$

The VAT announcement affected all German households. We cannot study the behavior of German households alone, because we miss a counterfactual. Our empirical design uses matched households in EU countries not exposed to the VAT shock as a control group for German households, in a difference-in-differences identification strategy. We match German and foreign households based on observables to ensure no systematic differences in the demographic composition of German and foreign households drive the results. We show directly that before the VAT announcement, no difference existed in the behavior of German households and households in other EU countries. In particular, German and foreign households behaved similarly in terms of inflation expectations and purchasing propensities before the VAT announcement. We cannot reject they follow parallel trends.

The VAT announcement increased German households' inflation expectations in 2006, and the increase in VAT increased actual consumer price inflation in 2007. The announcement did not affect the inflation expectations of households in other EU countries. The VAT announcement increased German households' willingness to purchase durable goods throughout 2006, with a peak of a $34 \%$ higher willingness to buy durable goods compared to other EU households in November 2006. A back-of-the-envelope calculation suggests the 3-percentage-point increase in VAT resulted in $10.3 \%$ higher real durable consumption growth.

Before studying the natural experiment, verifying that European households change their consumption decisions when their inflation expectations change is crucial. This condition is necessary for unconventional fiscal policy to affect consumption through intertemporal substitution. This baseline step is needed because earlier literature finds

\footnotetext{
${ }^{3}$ In Section V, we argue in more detail why this shock was unrelated to future economic conditions, and was exogenous to German households' expectations regarding current and future income.

${ }^{4}$ Policymakers believed the increase in consumer price inflation would be temporary and limited to Germany. Even the German representative on the ECB board at the time excluded an increase in nominal rates to offset inflationary pressure. Weber (2006): "We know what the effects of the VAT increase are; as is the case for oil prices, we do not consider one-off effects."
} 
conflicting results on the relationship between inflation expectations and household-level spending. Bachmann, Berg, and Sims (2015) and Burke and Ozdagli (2014), using data from the Michigan Survey of Consumers and the New York Fed Survey on Consumer Expectations, find no economically or statistically significant association between households' inflation expectations and their readiness to spend on durables. Using similar data from the New York Fed, Crump et al. (2015) find a large positive association. In Japan, Ichiue and Nishiguchi (2015) find households that expect higher inflation plan to decrease their future consumption spending.

We use micro data from the market research firm GfK. GfK surveys a representative set of 2,000 German households on a monthly basis to measure expectations about business-cycle conditions on behalf of the European Commission. Based on a sample from January 2000 through December 2013, Figure 1 shows a positive correlation between German households' inflation expectations and their willingness to purchase. The figure plots the average monthly willingness to purchase durable goods across surveyed households, against the share of households that expect higher inflation in the following 12 months. ${ }^{5}$ A positive correlation of 0.59 is present between inflation expectations and the readiness to spend on durable goods. This positive correlation is statistically different from zero throughout the sample period, and its size is larger after the announcement and before the actual VAT increase (blue points).

In our multivariate analysis, households that expect higher inflation are on average $8 \%$ more likely to report it is a good time to buy durable goods, compared to households that expect constant or decreasing inflation. Households expecting higher inflation are also less likely to save, which suggests overall consumption increases with higher inflation expectations. The average marginal effect of inflation expectations varies substantially across demographics. The association is higher for household heads with a college degree, for high-income households, and for non-retired households.

We then move on to the natural experiment. We first document the announcement of the VAT increase in November 2005 led to an increase in inflation expectations of Germans in 2006. Realized inflation increased in 2007 after the actual increase in VAT. Within the EU, this pattern was unique to Germany.

For identification, we proxy for the behavior of German households absent the shock with a group of similar households not affected by the shock. We obtained access to

\footnotetext{
${ }^{5}$ We describe the data and the construction of our variables in detail in Section II.
} 
Figure 1: Readiness to spend on durables and inflation expectations

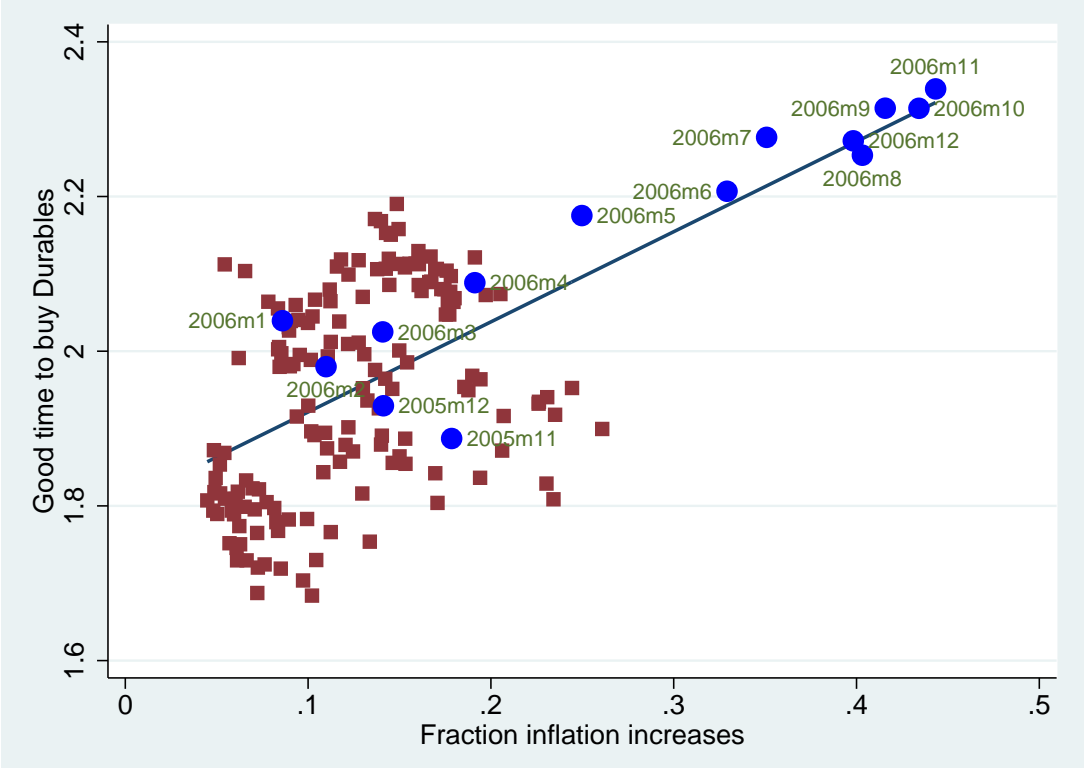

This figure plots the average monthly readiness to purchase durables on the y-axis against the average monthly inflation expectation. We use the confidential micro data underlying the GfK Consumer Climate survey to construct these variables. The sample period is January 2000 to December 2013.

confidential micro data from the same EU business-cycle survey for three additional countries: France, Sweden, and the UK. ${ }^{6}$ We first verify households in these countries behave similarly to German households before the shock, and are more willing to purchase durable goods when they expect higher inflation.

Our identification strategy is based on a difference-in-differences design: we compare German households' willingness to purchase durables with the willingness of households in other European countries, before and after the VAT shock. We match German households with foreign households that are observationally equivalent, because our baseline analysis shows substantial heterogeneity in the marginal effect of inflation expectations on consumption behavior across demographics. Consistent with a causal effect of unconventional fiscal policy on households' purchasing attitudes, we find a large treatment effect of the VAT shock on durable expenditure via increased inflation expectations of German households. We also find large effects of the unexpected increase in VAT using real durable consumption growth, which confirms the theoretical prescription

\footnotetext{
${ }^{6}$ All our results hold when we only use French households, as we discuss in Section IV.
} 
of Correia et al. (2013). ${ }^{7}$

In a large class of models, changes in VAT might affect households' decisions to purchase durable goods through income or wealth effects rather than inflation expectations. We show that German households' income expectations did not change after the government announced a change in VAT, and hence income effects cannot explain our results. As for wealth effects, changes in non-distortionary taxes do not change household behavior under Ricardian equivalence. If Ricardian equivalence fails, a tax increase results in a negative wealth effect, which would suggest our design identifies a lower bound of the true effect.

Inflation expectations might also affect consumption decisions through a redistribution channel in state-of-the-art heterogeneous-agent models. In Section IV, we argue a sizable redistribution channel is unlikely in our setting. We also argue housing-wealth effects and uncertainty channels are unlikely drivers of our results.

Shapiro (1991) emphasizes the effect of unconventional fiscal policy should mainly operate through expenditure on durable goods. A potential concern for policymakers aiming at stimulating overall consumption is that households might substitute intratemporally from non-durable to durable consumption, because our VAT change targeted nondurable goods less than durable goods. ${ }^{8}$ We do not observe directly households' attitudes toward purchases of non-durable goods. To address this concern, we show realized non-durable consumption growth increased in Germany during 2006, which is not consistent with intratemporal substitution driving our results. German households also lowered their savings attitudes during 2007 in absolute terms and relative to matched foreign households, which suggests households increased their overall consumption (see Table 6).

Using cross-sectional micro data to study the relationship between unconventional fiscal policy, inflation expectations, and willingness to spend has a set of advantages compared to using aggregate time-series data. First, the cross-sectional nature of the data allows us to document the time-varying effects of unconventional fiscal policy on purchasing behavior after the announcement and before the effectiveness of the VAT

\footnotetext{
${ }^{7}$ We discuss the relation between our empirical findings and the theoretical work of Correia et al. (2013) in Section V in detail.

${ }^{8}$ All services and products in Germany are subject to VAT. The general tax rate was $16 \%$ until December 2006, and increased to $19 \%$ in 2007. A reduced rate of $7 \%$ applies to many convenience goods such as food, books, or flowers. The reduced rate has been unchanged since 1983 .
} 
increase. Second, micro data allow us to match households based on their demographics, which is important because different demographics have different reactions to changes in inflation expectations. Last, our survey data allow us to control for income expectations, employment status, and housing choices that might affect the consumption response to the announcement of the VAT increase.

Our analysis contains caveats. The survey consists of repeated cross sections of households. We cannot exploit within-household variation in inflation expectations to control for time-invariant unobserved heterogeneity at the household level. The rich set of household demographics allows us to match households before and after the VAT announcement and across countries to alleviate this concern. Moreover, the survey elicits only a measure of households' willingness to purchase consumption goods, and we do not observe actual purchases. In Figure A.1 in the online appendix, we show households' average willingness to spend closely tracks the realized consumption expenditure on durables. A third potential shortcoming is that the survey elicits only qualitative measures of inflation expectations. However, evidence suggests quantitative inflation expectations bunch at salient threshold values, and households often report large positive and negative inflation expectations (see Binder (2015)).

\section{A. Related Literature}

Some recent papers study the effects of sales-tax changes on purchases (see, e.g., Crossley, Low, and Sleeman (2014), Cashin and Unayama (2015), and Cashin (2016)). Our research design and natural experiment have unique features that allow us to study the effect of unconventional fiscal policy compared to the VAT changes in these papers. A crucial difference is that the Japanese and the UK government had monetary and fiscal sovereignty to provide additional fiscal and monetary stimulus. The VAT changes in the UK and Japan were also unlikely to be exogenous to future economic prospects or unexpected. Moreover, changes in VAT affect the whole population of the UK and Japan, so these changes do not allow construction of counterfactuals based on households that live in the same monetary union. Because households' inflation and income expectations are not available in those data, one cannot use them to disentangle income or wealth effects from intertemporal substitution. Intertemporal substitution is the only channel through which announcements of VAT changes affect consumption in models of unconventional 
fiscal policy.

Papers that use sales-tax changes often aim to estimate the intertemporal elasticity of substitution (IES). We do not see our paper as part of this literature, because we focus on purchases of durable goods rather than on the flow consumption of durables. Changes in consumption taxes can increase expenditure through intertemporal substitution if households bring forward consumption. But tax changes can also alter expenditure when households bring forward expenditure of storable goods without changing consumption decisions, which is an arbitrage effect. Policymakers care about stimulative effects of inflation expectations, and shocks to inflation expectations might result in large increases in consumption expenditure even with small estimates of the IES. Studies in this literature either use aggregate time-series data, or do not observe household expectations and income, or cannot distinguish between prices and quantities. They do not incorporate the response of durable consumption into the IES estimate, or do not aim to rule out changes in VAT being related to future economic conditions, and therefore do not disentangle different channels or identify causal effects. We also differ from Cashin and Unayama (2015) and Cashin (2016), who assume any deviation in consumption from trend is due to the VAT change.

Pre-announced VAT increases are a salient way to generate future consumer price inflation. The salience of consumption taxes could be an advantage of using taxes to generate inflation and to engineer negative real interest rates (Wiederholt (2016)). A literature on the effect of sales-tax holidays suggests consumers in the United States change their consumption patterns around temporary changes in sales taxes (see Agarwal et al. (2013)). Sales-tax holidays in the United States are announced well in advance, and last for short periods of time around peaks of demand, such as back-to-school periods. They apply to a small set of goods. The predictability and seasonality of the tax holidays make consumers likely to shift consumption over time. The short time period, often just two or three days, and the small set of goods involved make assessing the macro implications and ruling out other channels difficult. In addition, the temporary tax cuts reduce tax revenues rather than being budgetary neutral or generating revenues. Sales-tax holidays can only be stimulative if they are not pre-announced (see Correia et al. (2013)).

We also relate to Mian and Sufi (2012) and Green, Melzer, Parker, and PfirrmannPowell (2014), who study fiscal stimulus offering temporary subsidies for the purchases of new cars. They document a temporary increase in car sales followed by a drop in 
sales. The car subsidy also changes intertemporal prices, but our paper differs in several ways. First, unconventional fiscal policy, contrary to government subsidies, does not lead to higher budget deficits, and is especially relevant in times of high government deficits. Moreover, we study how a change in VAT, which applies to almost all consumption goods, affects the overall willingness to purchase, as opposed to the purchases of specific items. We show our results operate through intertemporal substitution, whereas fiscal stimulus might operate through an income effect and/or intratemporal substitution.

Unconventional monetary policy, such as forward guidance, aims to generate inflation expectations through low interest rates until after the end of the liquidity trap. Future government spending also operates through an inflation-expectations channel. Bachmann et al. (2015) question the effectiveness of these policies, because they do not find any association between inflation expectations and consumption propensities. Dupor and Li (2015) do not find evidence consistent with government purchases stimulating inflation expectations. Del Negro, Giannoni, and Patterson (2015) and McKay, Nakamura, and Steinsson (2015) question the power of forward guidance. Unconventional fiscal policies might therefore be a suitable alternative to unconventional monetary policy and conventional fiscal policy, especially during periods of large government budget deficits and inflated central bank balance sheets.

Households with higher inflation expectations are more willing to purchase durable goods in all European countries we study and in periods outside of the VAT experiment. This result is consistent with a large theoretical literature that emphasizes the stabilization role of inflation expectations on the monetary policy and fiscal policy sides. ${ }^{9}$ From a historical perspective, Romer and Romer (2013) argue deflation expectations caused the Great Depression, whereas Eggertsson (2008) and Jalil and Rua (2016) suggest a fiscal and monetary policy mix engineered higher inflation expectations and spurred the recovery from the Great Depression. From an international perspective, Hausman and Wieland (2014) study the monetary easing of the Bank of Japan and the expansionary fiscal policy commonly known as "Abenomics." Their time-series evidence is consistent with higher inflation expectations raising consumption and GDP.

\footnotetext{
${ }^{9}$ For instance, see Krugman (1998), Eggertsson and Woodford (2003), Eggertsson (2006), Werning (2012), Eggertsson (2011), Christiano, Eichenbaum, and Rebelo (2011), Woodford (2011), and Farhi and Werning (2015).
} 


\section{Data}

\section{A. Data Sources}

We use the confidential micro data underlying the GfK Consumer Climate MAXX survey. GfK conducts the survey on behalf of the Directorate General for Economic and Financial Affairs (DG ECFIN) of the European Commission. ${ }^{10}$ GfK asks a representative repeated cross section of 2,000 German households questions monthly about general and personal economic conditions, inflation expectations, and willingness to spend on consumption goods. We obtained access to the micro data for the period starting in January 2000 and ending in December 2013. Our sample period includes large variation in macroeconomic fundamentals, two major recessions, and an unexpected increase in German VAT in 2007.

We use the answers to the following two questions in the survey to construct the main variables in our baseline analysis:

Question 8 Given the current economic situation, do you think it's a good time to buy larger items such as furniture, electronic items, etc.?

Households can answer, "It's neither a good nor a bad time," "No, it's a bad time," or "Yes, it's a good time."

Question 3 How will consumer prices evolve during the next twelve months compared to the previous twelve months?

Households can answer, "Prices will increase more," "Prices will increase by the same," "Prices will increase less," "Prices will stay the same," or "Prices will decrease." We create a dummy variable that equals 1 when households answer, "Prices will increase more," to get a measure of higher expected inflation. ${ }^{11}$

Households' inflation expectations are highly correlated with their perception of past inflation (see Jonung (1981)). We also use survey question 2 in our baseline analysis to disentangle the effects of inflation expectations from inflation perceptions:

Question 2 What is your perception on how consumer prices evolved during the last twelve months?

\footnotetext{
${ }^{10}$ We use similar data from the harmonized surveys of DG ECFIN for several other European countries in section IV. We discuss the data in more detail in the online appendix.

${ }^{11}$ Results do not change if we introduce separate dummies for the individual answer possibilities (see Table A.1 in the online appendix).
} 
Households can answer, "Prices increased substantially," "Prices increased somewhat," "Prices increased slightly," "Prices remained about the same," or "Prices decreased."

The online appendix contains the original survey and a translation to English.

We also use questions regarding expectations about general economic variables, personal income or unemployment, and a rich set of socio-demographics from the GfK survey. In robustness checks, we use data on contemporaneous macroeconomic aggregates, such as GDP and unemployment numbers from the German statistical office (DeStatis), nominal interest rates, the value of the German stock index DAX, and measures of European and German policy uncertainty from Baker, Bloom, and Davis (2016). The online appendix describes in detail the data sources and variable definitions.

\section{B. Descriptive Statistics}

Table 1 contains descriptive statistics. On average, $20 \%$ of households say it is a good time to buy durables, $24 \%$ say it is a bad time, and the others are indifferent. Fourteen percent of households expect higher inflation in the following 12 months. More than $80 \%$ of respondents think prices in the previous 12 months increased substantially, somewhat, or slightly, with equal proportions for each answer. Only $13 \%$ think prices remained the same, and essentially nobody thinks prices decreased.

The sample is balanced between women and men. Most respondents completed high school, but have no college education. ${ }^{12}$ The mean household's size is 2.5 , and the majority of households live in cities with fewer than 50,000 inhabitants.

Panel C of Table 1 reports statistics for households' personal expectations. Most households think their financial situation has not changed in the previous 12 months, and they expect the same for the future. Most households do not save or save only a little, and expect a constant or slightly increasing unemployment rate. In Panel D of Table 1, we describe descriptive statistics for the macroeconomic aggregates during our sample period.

We plot the time series of inflation expectations and the willingness to purchase durable goods in Figure 2, and verify the series are unconditionally highly correlated. Both inflation expectations and the average willingness to purchase spike after the announcement and before the actual increase in VAT.

\footnotetext{
${ }^{12}$ Most respondents completed either Hauptschule or Realschule, and only $8 \%$ of respondents have a college degree.
} 
Actual inflation increases in January 2007, but peaks later in the year (see Figure 3). Anecdotal evidence suggests many retailers delayed price increases because they feared a stark drop in demand. ${ }^{13}$ The German statistical office shows some categories immediately and fully adjusted prices, such as tobacco and services, whereas other categories adjusted prices with a delay, such as electronics and furniture. By early 2008, all categories underlying the German CPI had fully adjusted their prices by the theoretical amount. ${ }^{14}$ We discuss in detail in Section $\mathrm{V}$ the relation between inflation expectations and actual inflation, willingness to purchase durables, and actual purchases.

\section{Inflation Expectations and Consumption Expenditure}

Unconventional fiscal policy can affect purchasing propensities via an inflationexpectations channel only if households' willingness to purchase reacts to changes in their inflation expectations. In times of fixed nominal interest rates, the Euler and Fisher equations predict a positive association between consumption and inflation expectations. Earlier literature, however, found conflictive evidence in micro data for the United States. In this section, we document a positive association between households' inflation expectations and their willingness to purchase durable goods. The size of the association varies substantially across demographics. This result informs the construction of our difference-in-differences identification strategy that matches German households with demographically similar households in other EU countries.

\section{A. Econometric Model}

Our outcome variable of interest, households' readiness to purchase durable goods, derives from discrete, non-ordered choices in a survey. We therefore model the response probabilities in a multinomial-logit setting.

We assume the answer to the question on the readiness to spend is a random variable representing the underlying population. The random variable may take three values, $y \in\{0,1,2\}: 0$ denotes it is neither a good nor a bad time to purchase durable goods;

\footnotetext{
${ }^{13}$ We thank Emi Nakamura for emphasizing this point.

${ }^{14}$ See: https://www.destatis.de/DE/Publikationen/WirtschaftStatistik/Preise/MwSterhoehungJan2007.pdf.
} 
1 denotes it is a bad time to purchase durable goods; and 2 denotes it is a good time to purchase durable goods.

We define the response probabilities as $P(y=t \mid X)$, where $t=0,1,2$, and $X$ is an $N \times K$ vector where $N$ is the number of survey participants. The first element of $X$ is a unit vector, and the other $K-1$ columns represent a rich set of household-level observables, including demographics and expectations.

We assume the distribution of the response probabilities is

$$
P(y=t \mid X)=\frac{e^{X \beta_{t}}}{1+\sum_{z=1,2} e^{X \beta_{z}}}
$$

for $t=1,2$, and $\beta_{t}$ is a $K \times 1$ vector of coefficients. The response probability for the case $y=0$ is determined, because the three probabilities must sum to unity. We estimate the model via maximum likelihood to obtain the vector $\beta_{t}$ of coefficients for $t=1,2$, and set the category $y=0$ as the baseline response.

We compute the marginal effects of changes in the covariates on the probability that households choose any of three answers in the survey, and report them in the tables.

\section{B. Baseline Estimation}

Table 2 reports the average marginal effects computed from the multinomial logit regressions. We cluster standard errors at the quarter level (56 clusters) to allow for correlation of unknown form in residuals across contiguous months. In all columns, we report the marginal effect of the inflation-increase dummy on the likelihood that households respond that it is a good time to buy durables. In column (1), the inflation-increase dummy is the only explanatory variable. Households that expect increasing inflation over the following 12 months are on average $6.2 \%$ more likely to answer that it is a good time to buy durables compared to households that expect constant or decreasing inflation.

Perceptions of past inflation shape households' expectations about future inflation (Jonung (1981)). Controlling for past-inflation perceptions increases the marginal effect of inflation expectations on the willingness to buy durables (see column (2)). High perceptions of past inflation decrease the marginal propensity to consume durables, consistent with the consumption Euler equation. 
Households differ in their purchasing propensity (see, e.g., Attanasio and Weber (1993)). Household characteristics that determine both purchasing propensities and inflation expectations might be systematically related, and hence, controlling for the observed heterogeneity across households is important. In columns (3)-(5) of Table 2, we add a rich set of demographics, expectations about personal and macroeconomic variables, and contemporaneous macroeconomic variables. The results are similar across specifications. All marginal effects are virtually identical if we do not condition on past inflation. A back-of-the-envelope calculation implies the marginal effect of inflation expectations on the willingness to buy durables translates into $4.8 \%$ higher real durable consumption expenditure if all Germans expect higher inflation. During the period after the announcement and before the actual increase in VAT, our back-of-the-envelope calculation implies the increase in VAT by 3 percentage points resulted in a $10.3 \%$ higher real durable consumption growth. ${ }^{15}$

\section{Heterogeneity of the Effect}

Table 3 studies the variation in the baseline effect by household characteristics. We first consider respondents' education. Columns (1)-(2) of Table 3 report the marginal effects for our baseline specification estimated separately for survey participants with a Hauptschule degree (lowest level of formal education) and those with college education. Households with low levels of education that expect inflation to increase are $6.9 \%$ more likely to have a positive stance toward buying durables compared to households that expect constant or decreasing inflation (column (1)). This marginal effect increases with education, and is more than $60 \%$ larger for household heads that hold a college degree (column (2)).

We find a $20 \%$ higher marginal effect of inflation expectations on the likelihood of wealthier survey participants with a monthly net income above EUR 2,500 to reply that it is a good time to buy durables (column (4)), compared to survey participants with a monthly net income less than EUR 1,000 (column (3)).

Retirees have different time-use and consumption patterns compared to the working-age population (see Aguiar and Hurst (2005)), typically have nominal pensions

\footnotetext{
${ }^{15}$ To reach this suggestive conclusion, we regress the natural logarithm of real durable consumption expenditure at the quarterly frequency on the end-of-quarter value of the average durable purchasing propensity and quarterly dummies, and multiply the resulting coefficient of 0.5396 by the marginal effect of $8.88 \%$ (column (4) of Table 2) and $19.09 \%$ for the period of the natural experiment (see column (1) of Table A.2 in the online appendix).
} 
in Germany, hold few real assets, and have lower human capital compared to someone in the labor force. The marginal effect of inflation increases on the willingness to spend is lower for those aged 65 or higher (column (6)) than for the younger population (column $(5))$.

\section{Natural Experiment and Identification Strategy}

\section{A. Exogenous Measure of Unconventional Fiscal Policy}

The ideal experiment to test for the effect of unconventional fiscal policy on consumption expenditure would consist of an exogenous increase in future consumption taxes with an accompanying cut in income taxes to offset the effect of consumption taxes on labor supply and real wages. To the best of our knowledge, no country has yet explicitly implemented the full set of measures of unconventional fiscal policy discussed by Correia et al. (2013) and others. We thus identify an exogenous policy shock that closely resembles unconventional fiscal policy following a narrative approach (see Romer and Romer (2010)). This measure should be unexpected, should not increase the budget deficit, and should have affected households' inflation expectations, but not their income expectations.

In November 2005, the newly formed German government unexpectedly announced a 3-percentage-point increase in the VAT, effective January 2007. The narrative record suggests the VAT increase was legislated for reasons unrelated to future economic conditions. The EU mandated the increase to ensure the German deficit over GDP would fall below $3 \%{ }^{16}$

In each year between 2001 and 2004, Germany posted a deficit-to-GDP ratio above 3\%. In 2003, the European Commission opened a procedure against Germany for infringement of the 3\% deficit-to-GDP rule. The German government proposed plans to reduce the ratio to $2.9 \%$ in 2005 to avoid fines. It became obvious during 2005 that Germany could not deliver on its promises, and the actual deficit-to-GDP ratio was 3.3\% for 2005. The European Commission re-opened the deficit procedure and announced in November of 2005 it would fine Germany if the ratio was not below $3 \%$ by the end of 2007. The newly elected right-left government announced in November 2005 an increase

\footnotetext{
${ }^{16}$ The Maastricht Treaty of 1992 requires all EU countries to have "annual deficits no greater than $3 \%$ of GDP."
} 
in VAT by 3 percentage points, from 16\% to 19\%, effective in January 2007.

The increase in VAT was unrelated to future economic conditions in Germany, and it was adopted to satisfy the requirements of the EU Stability and Growth Pact. ${ }^{17}$ Based on these reasons, we argue the VAT increase falls within the exogenous tax-change category following the taxonomy of Romer and Romer (2010).

A pre-announced VAT increase in a fixed-nominal-rates environment resembles the unconventional fiscal policies to stimulate spending through higher inflation expectations described in Correia et al. (2013). Hall and Woodward (2008) argue along similar lines for sales-tax holidays to generate an increasing path of consumption taxes over time and stimulate current spending. Hall (2011) emphasizes the use of consumption taxes to alter intertemporal prices.

The announcement of the VAT increase is a shock to inflation expectations, and should result in higher consumption expenditure as long as nominal interest rates do not increase sufficiently to leave real rates constant. Germany is part of the Euro area, and the ECB is responsible for monetary policy and price stability in the whole currency union. The ECB did not tighten monetary policy to counteract the increase in inflation expectations in Germany. Nominal borrowing rates for consumption loans were $6.7 \%$ in January 2006 and 6.4\% in December 2007 (see Figure A.2 in the online appendix).

The VAT increase in January 2007 should result in higher inflation expectations of German households throughout 2006. Figure 3 shows German households started to adjust their inflation expectations upwards immediately in January 2006. Inflation expectations remained high for the rest of 2006, and reverted once the VAT increase was in effect in January 2007. Realized inflation started to increase in January of 2007, and remained high throughout the year.

\section{B. Difference-in-Differences Approach}

The VAT shock alone does not allow a causal test for the effect of unconventional fiscal policy on consumption expenditure, because all German households were exposed to the same shock. For identification, we miss a counterfactual: a group of households not affected by the shock, but similar to German households before the shock. We design a strategy in the spirit of Poterba (1996) and Besley and Rosen (1999).

\footnotetext{
${ }^{17}$ We discuss in more detail the narrative sources, the scope of the VAT increase, and the relation between future VAT increases and inflation expectations in Section V.
} 
The European Commission conducts harmonized surveys in all EU countries. We obtained access to the confidential micro data for three additional countries (France, Sweden, and the UK) through national statistical offices and GfK subsidiaries. We use the households in these three countries to construct our control group.

Our identification strategy is a difference-in-differences approach: we compare German households' readiness to purchase durables with that of households in other European countries, before and after the VAT shock.

We estimate the average treatment effect of the VAT shock on the readiness to purchase durables as

$$
\left(\overline{D u r}_{\text {German, post }}-\overline{D u r}_{\text {German, pre }}\right)-\left(\overline{\text { Dur }}_{\text {foreign, post }}-\overline{D u r}_{\text {foreign, pre }}\right),
$$

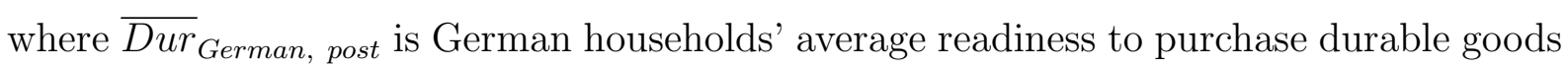

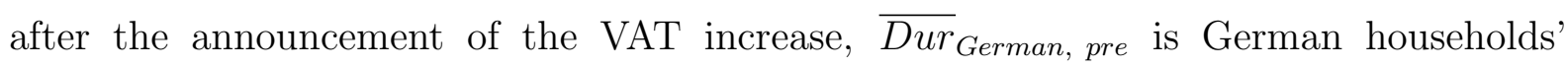
average readiness to purchase durable goods before the announcement of the VAT increase, and $\overline{D u r}_{\text {foreign, post }}$ and $\bar{D}_{\text {Dur }}$ foreign, pre are the analogous averages for foreign households not exposed to the VAT shock.

\section{Identifying Assumptions}

The parallel-trends assumption is a necessary condition for identification. In our case, it requires that our control group behaved similarly to German households both before and after the shock, had the shock not happened. We cannot test whether the parallel-trends assumption holds after the shock, because we miss the counterfactual of no shock. We therefore test whether the trends are parallel before the shock. If they are, our identifying assumption will be that foreign households behave like German households would have behaved absent the shock throughout the sample period.

The top panels of Figure 4 and Figure 5 provide graphical evidence that the paralleltrends assumption seems satisfied in our setting. The trends in inflation expectations and purchasing propensities are parallel for German and foreign households before the announcement of the VAT increase (November 2005). Starting in January 2006, both the German households' inflation expectations and willingness to buy durable goods start to increase substantially. Trends for foreign households do not move compared to the pre-shock period. 
The middle panels of Figure 4 and Figure 5 repeat the exercise when comparing German households to French households only. France and Germany face the same monetary policy, share a common border, and are structurally similar. The similarity of pre-shock trends is even more pronounced when we only use French households as a control group. In the bottom panels of Figure 4 and Figure 5, we also compare the trends for German households and for households in the UK and Sweden. Cavallo, Neiman, and Rigobon (2014) show firms within the euro area harmonize prices of durable goods. ${ }^{18}$ Even in this case, the parallel-trends assumption seems plausible.

Importantly, Table 4 verifies households in each of the three foreign countries display a positive association between inflation expectations and willingness to consume durable goods (columns (1)-(3)). In column (4), we report the corresponding baseline effect for German households, excluding the period after the announcement of the VAT increase and before the actual increase. Foreign households are therefore likely to react to increases in inflation expectations in a similar fashion as German households, which alleviates the concerns regarding the external validity of our strategy.

\section{Matching Foreign and German Households}

We match households in Germany with households abroad to account for the heterogeneity in responsiveness to inflation expectations we document in Section III, and the large heterogeneity in marginal propensities to consume to fiscal policy shocks Jappelli and Pistaferri (2014) document. We first match each German household in each month with a household in another country, interviewed in the same month, with similar demographic characteristics. We use a nearest-neighbor algorithm to match households based on propensity scores. ${ }^{19}$ We estimate propensity scores with a logit regression of the treatment indicator on gender, age, education, income, and social status. Our samples are repeated cross sections, and we cannot track German and matched foreign households before and after the shock. We perform a second level of matching, which pairs up similar households interviewed before and after the shock separately within the German and the foreign survey waves.

\footnotetext{
${ }^{18}$ We thank Brent Neiman for suggesting this test.

${ }^{19}$ All the results are virtually identical if we perform the monthly matching using a group of control households for each German household, and we minimize the difference in observables of the German household and the group of foreign households.
} 
The matching exercise is meaningful only for German and foreign households in the common support of the distributions of the propensity score for the two groups. In Figure 6 , we plot the distribution of the propensity score for the treatment group (red) and the control group (blue). Households are distributed across the full range of the propensity score in both groups.

Moreover, we formally test whether household characteristics are balanced after the matching process. In Table 5, we report the mean of the matching categories for matched households in the control group and treated group as of June 2005, our baseline month before the announcement of the VAT increase. Columns (3) and (4) test the null hypothesis that the means across the two groups are equal. We cannot reject the null for any of the five matching variables.

All our results are similar or become stronger if we only use households from France as a control group. Using a larger pool of control households increases the size of the common support, and improves the balancing of matched households' characteristics ex post.

\section{E. Threats to Identification}

Changes in VAT might affect households' decisions to purchase durables through channels different from inflation expectations. A positive average treatment effect in equation (2) might reflect those other channels, in which case we could interpret our finding only as an impulse response of consumption expenditure to the announcement of a VAT increase, as opposed to the causal effect of unconventional fiscal policy on consumption expenditure through inflation expectations. We test below whether the VAT shock affected households' expectations other than inflation expectations, which might affect the readiness to spend on durables irrespective of inflation expectations and discuss alternative channels.

The change in VAT could affect the consumption behavior of Germans through income and wealth effects rather than intertemporal substitution. The increase in VAT might lead households to adjust their income expectations upward. ${ }^{20}$ Figure 7 plots the evolution of average income perceptions and income expectations over the next 12 months together with inflation expectations. The announcement of the VAT increase does immediately increase average inflation expectations, whereas the average perception

\footnotetext{
${ }^{20}$ Jappelli and Pistaferri (2010) provide a recent overview of the literature on the consumption response to income changes.
} 
of income and the average expectation of future income do not move.

An announced increase in non-distortionary taxes should not alter the behavior of German households through wealth effects in a Ricardian world. If Ricardian equivalence does not hold, an increase in non-distortionary taxes should result in a negative wealth effect and lower consumption expenditure. ${ }^{21}$ We would identify a lower bound of the causal effect in such a world.

Modern heterogeneous-agent models prominently feature a redistribution channel of surprise inflation from lenders to borrowers (see Doepke and Schneider (2006)). Under the assumptions of all goods being subject to the higher VAT and $100 \%$ tax incidence on the consumer side, we would expect an increase in consumer price inflation of $2.59 \%$. However, the change in inflation is only a surprise for loan contracts that existed already before November of 2005 and matured after December 2006. For this subset of contracts, we do expect a redistribution of nominal wealth from lenders to borrowers after the actual increase in VAT. At the same time, the increase in VAT was permanent and should result in a reduction in wealth corresponding to $2.59 \%$ of lifetime consumption under the assumption that consumers do not change their consumption bundle after the VAT announcement. The net wealth effect of an increase in VAT is therefore most likely negative for both borrowers and lenders, and we would again identify a lower bound.

More elaborate models with financial constraints or hand-to-mouth consumers might offer alternative channels. We cannot test for all alternative channels with our data. However, financial constraints or hand-to-mouths behavior are unlikely to drive our findings, because tax increases should result in lower consumption expenditure in these alternative models.

A housing-wealth channel and home-equity extraction were contributors to the boom before the Great Recession (see, e.g., Mian and Sufi (2011)). Germany has a homeownership rate of only around $43 \%$ compared to two thirds in the United States, but also experienced negative house-price inflation throughout the 2000s (see Figure A.3 in the online appendix). Appendix Table A.3 shows similar marginal effects for renters and owners. A housing-wealth channel is therefore not likely to be an important contributor to our findings.

We discuss in Section $\mathrm{V}$ other concurrent policy changes, one of which was the abolition of the homeowner subsidy. One potential channel might be a substitution away

\footnotetext{
${ }^{21}$ Consumption taxes and VAT are, of course, distortionary.
} 
from home purchases to purchases of other durable goods. Using data from the German Sample Survey of Income and Expenditure, we find a stable homeownership rate of 43.0\% in $2003,43.2 \%$ in 2008 , and $43.0 \%$ in 2013 . A substitution away from home purchases to purchases of other durable goods is therefore unlikely to explain our findings.

Bloom (2009) and Bloom et al. (2016) argue uncertainty shocks could be a major driver of business cycles. Higher uncertainty might result in lower consumption due to a precautionary-savings motive. Using the policy uncertainty index of Baker, Bloom, and Davis (2016), we do not see noticeable differences in uncertainty across Germany, France, and the UK (see Figure A.4 in the online appendix). ${ }^{22}$ An increase in uncertainty occurs in September 2005 in Germany, which was the month of the general election. During the period of our difference-in-differences test, uncertainty is effectively flat across countries. ${ }^{23}$

An intratemporal substitution from non-durable to durable consumption without increasing overall consumption might be another alternative channel we want to discuss. Figure 8 plots the real durable and non-durable consumption growth at the quarterly frequency. Real durable consumption growth increases sharply during 2006. However, non-durable consumption growth also increases and is above historical averages during this period. Table 6 shows households expecting higher inflation are more likely to report it is a bad time to save compared to households with constant or decreasing inflation expectations. Both sets of results make an intratemporal substitution channel driving our findings unlikely.

\section{F. Causal Effect of VAT Shock on Willingness to Buy Durables}

We run a set of cross-sectional regressions on the matched sample before and after the announcement of the VAT increase to estimate the average treatment effect of the VAT shock in equation (2). We set the reference month to June 2005, and we change the end month $m$ across regressions. All the results are similar if we use any other month before the announcement of the VAT increase in November 2005.

We estimate the following specification:

$$
\Delta \text { Dur }_{i, 06 / 2005 \rightarrow m}=\alpha+\beta_{m} \times V \text { ATshock }_{i}+\Delta X_{i, 06 / 2005 \rightarrow m}^{\prime} \times \gamma+\epsilon_{i},
$$

\footnotetext{
${ }^{22}$ We thank Rudi Bachmann for suggesting we test for an uncertainty and policy confidence channel.

${ }^{23}$ Baker et al. (2016) do not provide uncertainty data for Sweden. All our results hold if we exclude Sweden from the analysis.
} 
where $\Delta D u r_{i, 06 / 2005 \rightarrow m}$ is the difference in the willingness to spend on durable goods

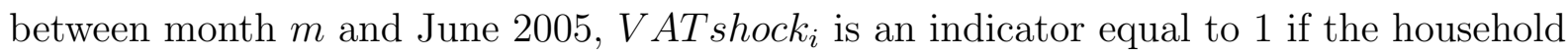
was exposed to the VAT shock, $\beta_{m}$ captures the effect of the VAT shock on household $i$ 's willingness to buy durables in month $m$, and $\Delta X_{i, 06 / 2005 \rightarrow m}^{\prime}$ is the difference in a set of observables between month $m$ and the baseline month. The observables include the matching variables we use to construct households pairs, as well as income expectations. The results are virtually identical if we change the set of observables, or we exclude them altogether.

Figure 9 plots the estimated coefficient $\hat{\beta}_{m}$ (solid line) of equation (3) for each month $m$ from July 2005 to December 2007, as well as the 95\% confidence intervals (dashed line). We find no difference in the readiness to spend on durable goods between German and matched households before the announcement of the VAT increase. Starting in December 2005, the VAT shock results in a positive effect on the willingness of German households to purchase compared to matched households: German households are 3.8 percentage points (s.e. 1.5 percentage points) more likely to declare it is a good time to purchase durable goods after the announcement compared to before, and compared to matched foreign households. The effect increases in magnitude throughout 2006 and peaks at 34 percentage points in November 2006. The average treatment effect drops to zero in January 2007 once VAT increases and higher inflation materializes. ${ }^{24}$

Figure 9 shows the VAT shock has a strong and positive effect on the willingness of German households to purchase durable goods after the announcement and before the increase took effect, even after controlling for the purchasing propensities of similar households not exposed to the shock in a difference-in-differences setting. The average treatment effect increases over time. This finding is consistent with Crossley et al. (2014), who argue intertemporal arbitrage should increase over time and be highest right before the tax increase, because of irreversibility, uncertainty, and storage costs.

\footnotetext{
${ }^{24}$ Figure A.5 in the online appendix plots the average treatment effect of a specification in which we match on income expectations for the next 12 months, in addition to gender, age, education, income, and social status. Results are virtually identical.
} 


\section{Discussion}

In this section, we describe in detail the narrative records surrounding the 2005 general elections in Germany, and the relationship between willingness to spend and actual spending, inflation expectations and actual inflation, the mapping of our findings into the framework of Correia et al. (2013), the marginal effect of inflation expectations on consumption expenditure over time, salience of VAT changes, and the differences between reduced and full VAT rates.

2005 electoral campaign platforms and election outcome: The Christian Democrats (CDU, center-right) were the only German party in the 2005 electoral campaign advocating an increase in VAT by $2 \%$ starting in January 2006 to lower non-wage labor costs (see CDU (2005), page 14). The Social Democrats (SPD, center-left) strongly opposed an increase in VAT, and instead favored a $3 \%$ increase in income tax for top income earners (see SPD (2005), page 39). The Greens (center-left) and Liberals (center-right) also strongly opposed an increase in VAT. The Liberals, for example, promised to decrease the general tax burden by EUR $19 \mathrm{bn}$.

All parties except the CDU strongly opposed raising VAT, including CDU's preferred coalition partner, the Liberals. The projections of the election outcomes were highly uncertain (see below), as well as the fiscal policy measures the new government would have implemented. A VAT increase of $3 \%$ was therefore highly unexpected. Consistently, the opposition parties and the popular press accused the new government between CDU and SPD of electoral fraud after it announced this policy measure in November 2005, and they fiercely criticized the new government. The online appendix contains press clippings commenting on the VAT policy (see Section III of the online appendix).

Figure 2 is direct evidence that German households did not expect an increase in VAT in 2006, as the CDU proposed: households' inflation expectation over the next 12 months did not increase until January 2006, after the new government had announced its plans in November 2005 to increase VAT in 2007, rather than 2006 as the CDU had planned initially. ${ }^{25}$

Neither of the two blocks - CDU and Liberals on the one hand, and SPD and Greens

\footnotetext{
${ }^{25}$ If voters had considered the CDU proposal credible, we should already see an increase in inflation expectation during the campaign in the summer of 2005, because the plan was to increase VAT in January 2006.
} 
on the other hand - had a majority in polls before the elections. ${ }^{26}$ In the actual election on September 18, 2005, the CDU gained 35.2\% electoral support; the SPD, $34.2 \%$; the Liberals, 9.8\%; the Left, 8.7\%; and the Greens, 8.1\%. Neither the CDU nor the SPD were able to form a "small" coalition with their preferred coalition partner (Liberals and Greens, respectively). The CDU and SPD therefore agreed to form a "grand" coalition.

The coalition agreed on an overall contractionary fiscal policy (see below), including the increase of VAT by 3\%, and the use of one third of the additional tax revenue to decrease non-wage labor costs by two percentage points. The government planned to use two thirds of the VAT increase to consolidate the federal budget to comply with the Maastricht Treaty and hinder an infringement procedure by the European Commission. Table A.5 in the online appendix shows the total tax revenue indeed increased in 2007, and Germany no longer violated the EU Stability and Growth Pact.

Other Policy Measures: The new government announced additional policy measures as part of its coalition agreement. The preamble of the official agreement emphasizes the need to reduce Germany's public debt as the major challenge for the new government, and the set of agreed-upon policy measures would be contractionary overall. In addition to the VAT increase and the non-wage labor-costs reduction, the government announced an investment program of $0.25 \%$ of 2005 GDP per year over the following four years. The government planned to finance the majority of the program through budget cuts. Moreover, the government announced an increase in the top marginal income tax rate from $42 \%$ to $45 \%$ for incomes above EUR 250,000 for singles and EUR 500,000 for couples. Lastly, the government planned to increase indirect taxes for retirement from $19.4 \%$ to $19.9 \%$, and it abolished the home-buyer subsidy, which had been guaranteed since 1949, and amounted to EUR 11.4 billion in 2004. ${ }^{27}$ The overall contractionary nature of this set of policies suggests our estimates in Section IV represent a lower bound of the positive effect of the announcement to increase VAT in 2007 on households' willingness to purchase durables.

\footnotetext{
${ }^{26}$ Eleven days before the elections, the polling institute Infratest Dimap predicted a vote share of $41 \%$ for the CDU, $34 \%$ for the SPD, $8.5 \%$ for the Left, $7 \%$ for the Greens, and $6.5 \%$ for the Liberals. See http://www.infratest-dimap.de/en/umfragen-analysen/bundesweit/sonntagsfrage/. All parties explicitly ruled out any coalition with the Left. The media mentioned all other possible combinations, including non-traditional combinations, as possible coalitions, including a "traffic-light" coalition among SPD, Greens, and Liberals and a "Jamaica" coalition among CDU, Liberals, and Greens.

${ }^{27}$ See http://www.kas.de/upload/ACDP/CDU/Koalitionsvertraege/Koalitionsvertrag2005.pdf for details.
} 
Willingness to Spend versus Actual Spending: We are ultimately interested in how inflation expectations transform into actual consumption expenditure. Our survey only reports the willingness to purchase durable goods. Figure A.1 in the online appendix is a scatter plot of the cyclical components of log real durable consumption expenditure and the average propensity to purchase durables. ${ }^{28}$ Real and reported spending on durables are positively related. Their correlation is 0.46 .

The reported willingness to purchase has potential advantages compared to measures of actual expenditures elicited with surveys. Spending data in surveys typically contain noise, because survey participants might not recall their actual purchases, or they might overstate their purchases of visible products, such as cars, and understate the consumption of "sin" products, such as tobacco and alcohol (see Hurd and Rohwedder (2012) and Atkinson and Micklewright (1983)).

Empirical Evidence and Relationship with Theory: Correia et al. (2013) study theoretically unconventional fiscal policy and show it can fully circumvent the zero lower bound constraint on nominal interest rates in a budget-neutral and time consistent manner. Their benchmark model is a textbook New Keynesian model, in which labor is the only factor of production. In this setup, an increasing path of consumption taxes generates inflation expectations and negative real interest rates. Lower labor income taxes ensure consumption taxes do not affect the intratemporal margin between leisure and consumption, and hence the real wage. Firms' pricing decisions are independent of the change in consumption taxes, and marginal costs do not change either. Therefore, the production allocation across firms is efficient and the government can offset the distortion coming from monopoly rents with taxes as in the textbook model.

Our natural experiment is close to the theoretical framework in Correia et al. (2013), but deviates in a few dimensions we now discuss. First, the German government used 2 percentage points of the increase in VAT by $3 \%$ to consolidate the federal budget, and 1 percentage point to lower indirect labor taxes by $2 \% .{ }^{29}$ Empirically, we do not find any

\footnotetext{
${ }^{28}$ We use a Hodrick-Prescott filter with smoothing parameter $\lambda$ of 1,600 to extract the cyclical component.

${ }^{29}$ Efficiency gains in the unemployment insurance system financed the second percentage-point decrease in indirect labor taxes.
} 
effect on labor supply or unit labor costs. ${ }^{30}$ Moreover, we find similar marginal effects of inflation expectations on the propensity to purchase durables for full-time, part-time, and unemployed survey participants (see appendix Table A.4). In addition, Nakamura, Steinsson, Sun, and Villar (2016) question whether producer price dispersion has real economic costs.

Second, we only observe attitudes towards purchases of durable goods. In a model with both durable and non-durable consumption, the intertemporal substitution effect of higher future consumption taxes is larger for durable goods (see Barsky et al. (2007) and Barsky et al. (2016)). ${ }^{31}$ A potential concern for policymakers aiming to stimulate overall consumption is that households might substitute intratemporally from non-durable to durable consumption, because the VAT change did affect nondurable goods less than durable goods (see discussion below). We do not observe households' attitudes towards purchases of non-durable goods. To address this concern directly, we show realized nondurable consumption growth increased during 2006. German households also lowered their savings attitudes during 2007 in absolute terms and relative to matched foreign households, supporting the conclusion that households increased overall consumption (see Table 6).

Third, Correia et al. (2013) study unconventional fiscal policies during a liquidity trap, whereas we study the effect for a single country in a currency union. To predict higher consumption, the consumption Euler equation requires only that nominal interest rates not be increasing sufficiently to offset the increase in inflation expectations rather than being in a liquidity trap. The ECB explicitly excluded an increase in nominal interest rates to counteract the announcement of a higher VAT in Germany, because it believed the increase in consumer price inflation would be temporary and limited to Germany. The then-president of the German Bundesbank excluded an increase in nominal rates to offset inflationary pressure: "We know what the effects of the VAT increase are; as is the case for oil prices, we do not consider one-off effects" (see Weber (2006)). Nominal interest

\footnotetext{
${ }^{30}$ Data from the OECD show unit labor costs decreased in Germany during 2006 and 2007 in absolute terms and relative to France, Sweden, and the UK (see: http://stats.oecd.org/Index.aspx?QueryName=426). Labor force participation, instead, slightly increased from $58.4 \%$ in 2005 to $59.1 \%$ in 2007 (see: http://data.worldbank.org/indicator/SL.TLF.CACT.ZS?locations=DE).

${ }^{31}$ Shapiro (1991) already emphasizes the effect of unconventional fiscal policy should mainly operate through expenditure on durable goods. Storability of durable goods can lead to an increase in durable expenditure due to a future increases in VAT even if the IES is small through an arbitrage effect.
} 
rates for consumption loans also barely changed and were 6.7\% in January 2006 and $6.4 \%$ in December 2007 (see appendix Figure A.2). Moreover, in our difference-in-differences estimation in Section IV, we compare the behavior of German households to matched French households that face the same nominal interest rates as German households.

Last, we study the pre-announced increase in VAT rather than consumption taxes. Correia et al. (2013) already highlight both VAT and consumption taxes should have similar implications because of "the extensive evidence of very high pass-through of consumption taxes even in the cases in which the usual practice is to quote after-tax prices, as is the case for the value-added tax in Europe." This point is consistent with the ex-ante expectations for the specific case of the VAT increase in Germany and the actual ex-post result. The Association of Consumer \& Home Electronics expected the increase in VAT would be fully passed through to consumers (see Stehle (2006)). Ex-post, the German statistical office shows some categories immediately and fully adjusted prices, such as tobacco and services, whereas other categories adjusted prices with a delay, such as electronics and furniture. By early 2008, all categories underlying the German CPI had fully adjusted their prices by the theoretical amount. ${ }^{32}$

Marginal Effect over Time: In Figure 2, we see a large increase in inflation expectations before the introduction of the euro in 2002, and after the announcement and before the actual increase in VAT in January of 2007. To ensure these two periods do not drive our baseline results in Table 2, we plot in Figure A.6 in the online appendix the marginal effect over time. We find a positive and statistically significant marginal effect of $6 \%$ throughout the sample period, which increases to $19 \%$ during our natural experiment (see also Table A.2 in the online appendix).

Salience of VAT Changes: Pre-announced VAT increases are a salient way to generate future consumer price inflation and induce current spending compared to conventional and unconventional monetary policy or future government purchases. Menz and Poppitz (2013) study the media coverage of inflation in Germany during the time period of our natural experiment and document a surge in coverage of inflation. The salience of consumption taxes could be an advantage of using taxes to engineer negative real interest rates compared to forward guidance or announcements of future government purchases.

Reduced and Full VAT Tax: All services and products in Germany are subject

\footnotetext{
${ }^{32}$ See https://www.destatis.de/DE/Publikationen/WirtschaftStatistik/Preise/MwSterhoehungJan2007.pdf.
} 
to a value-added tax that is part of the European VAT system. The general tax rate was $16 \%$ until December 2006, and increased to $19 \%$ in 2007. A reduced rate of $7 \%$ applies to many convenience goods, such as food, books, or flowers. The reduced rate has been unchanged since 1983. Rent, services for non-profit organizations, and medical expenses are not subject to VAT. Virtually all durable goods are subject to the full VAT, whereas only $59 \%$ of non-durables are subject to a VAT rate of $19 \%$.

\section{Concluding Remarks}

We propose a causal test for the effect of unconventional fiscal policies on households' consumption attitudes. We test for the effect of a pre-announced increase in value added tax (VAT) on the willingness of households to buy durable goods through an inflationexpectations channel.

The natural experiment we exploit for identification - an announcement in 2005 to increase German VAT in 2007-is unique because the increase was unexpected, and the EU imposed it to comply with its budgetary requirements. It was exogenous to the expectations of German households. Moreover, the European Central Bank explicitly stated it would not increase nominal interest rates to combat an expected increase in inflation, which it considered temporary and locally confined.

We use observationally similar households in other European countries not exposed to the VAT shock as a counterfactual in a difference-in-differences identification design.

The announcement of an increase in VAT led to an increase in German households' inflation expectations and in their willingness to buy durable goods, compared to households in other European countries exposed to the same macroeconomic environment but not exposed to the VAT shock. The announcement did not change households' expectations regarding future income, suggesting income effects do not drive our findings. We find an intratemporal substitution channel from non-durable to durable goods, wealth effects, redistribution through inflation, political uncertainty, or a housing wealth channel are unlikely explanations for the effect of the VAT shock on spending attitudes.

Our results suggest budget-neutral unconventional fiscal policies can be a viable alternative to unconventional monetary and conventional fiscal policy to stimulate aggregate demand, especially in times of large government budget deficits and inflated central bank balance sheets. Unconventional fiscal policy is salient, budget neutral, and 
affects the whole population. Governments can change VAT in a timely manner, which are further advantages compared to income tax rebates or direct payments to households. 


\section{References}

Agarwal, S., N. Marwell, and L. McGranahan (2013). Consumption responses to temporary tax incentives: Evidence from state sales holidays. Unpublished Manuscript, University of Wisconsin.

Aguiar, M. and E. Hurst (2005). Consumption versus expenditure. Journal of Political Economy 113(5), 919-948.

Atkinson, A. B. and J. Micklewright (1983). On the reliability of income data in the family expenditure survey 1970-1977. Journal of the Royal Statistical Society. Series A (General) 146(1), 33-61.

Attanasio, O. P. and G. Weber (1993). Consumption growth, the interest rate and aggregation. The Review of Economic Studies 60(3), 631-649.

Bachmann, R., T. O. Berg, and E. Sims (2015). Inflation expectations and readiness to spend: Cross-sectional evidence. American Economic Journal: Economic Policy 7(1), $1-35$.

Baker, S. R., N. Bloom, and S. J. Davis (2016). Measuring economic policy uncertainty. Quarterly Journal of Economics (forthcoming).

Barsky, R. B., C. Boehm, C. L. House, and M. S. Kimball (2016). Monetary policy and durable goods. Unpublished Manuscript, University of Michigan 97(3), 984-998.

Barsky, R. B., C. L. House, and M. S. Kimball (2007). Sticky-price models and durable goods. The American economic review 97(3), 984-998.

Besley, T. J. and H. S. Rosen (1999). Sales taxes and prices: an empirical analysis. National Tax Journal 52(2), 157-178.

Binder, C. (2015). Consumer inflation uncertainty and the macroeconomy: Evidence from a new micro-level measure. Unpublished Manuscript, UC Berkeley.

Bloom, N. (2009). The impact of uncertainty shocks. Econometrica r7(3), 623-685.

Bloom, N., M. Floetotto, N. Jaimovich, I. Saporta-Eksten, and S. J. Terry (2016). Really uncertain business cycle. NBER Working Paper 18245.

Burke, M. A. and A. Ozdagli (2014). Household inflation expectations and consumer spending: evidence from panel data. Unpublished Manuscript, Federal Reserve Bank of Boston 13(25), 1-43.

Cashin, D. (2016). The household expenditure response to a consumption tax rate increase. Unpublished Manuscript, Federal Reserve Board.

Cashin, D. and T. Unayama (2015). Measuring intertemporal substitution in consumption: Evidence from a VAT increase in Japan. Review of Economics and Statistics 98(2), 285-297.

Cavallo, A., B. Neiman, and R. Rigobon (2014). Currency unions, product introductions, and the real exchange rate. The Quarterly Journal of Economics 129(2), 529-595.

CDU (2005). Deutschlands Chancen nutzen. Wachstum. Arbeit. Sicherheit. Electoral Manifest.

Christiano, L., M. Eichenbaum, and S. Rebelo (2011). When is the government spending multiplier large? Journal of Political Economy 119(1), 78-121.

Correia, I., E. Farhi, J. P. Nicolini, and P. Teles (2013). Unconventional fiscal policy at the zero bound. American Economic Review 103(4), 1172-1211.

Crossley, T., H. Low, and C. Sleeman (2014). Using a temporary indirect tax cut as a fiscal stimulus: evidence from the UK. Unpublished Manuscript, University of Essex.

Crump, R. K., S. Eusepi, A. Tambalotti, and G. Topa (2015). Subjective intertemporal substitution. FRB of New York Staff Report (734).

Del Negro, M., M. P. Giannoni, and C. Patterson (2015). The forward guidance puzzle. 
FRB of New York Staff Report (574).

Doepke, M. and M. Schneider (2006). Inflation and the redistribution of nominal wealth. Journal of Political Economy 114(6), 1069-1097.

Dupor, B. and R. Li (2015). The expected inflation channel of government spending in the postwar U.S. European Economic Review 74, 36-56.

Eggertsson, G. B. (2006). The deflation bias and committing to being irresponsible. Journal of Money, Credit and Banking 38(2), 283-321.

Eggertsson, G. B. (2008). Great expectations and the end of the depression. The American Economic Review 98(4), 1476-1516.

Eggertsson, G. B. (2011). What fiscal policy is effective at zero interest rates? In NBER Macroeconomics Annual 2010, Volume 25, pp. 59-112. University of Chicago Press.

Eggertsson, G. B. and M. Woodford (2003). The zero bound on interest rates and optimal monetary policy. Brookings Papers on Economic Activity 2003(1), 139-211.

Eggertsson, G. B. and M. Woodford (2004). Optimal monetary and fiscal policy in a liquidity trap. In NBER International Seminar on Macroeconomics 2004, pp. 75-144. The MIT Press.

Farhi, E. and I. Werning (2015). Fiscal multipliers: Liquidity traps and currency unions. Unpublished Manuscript, MIT.

Feldstein, M. (2002). The role for discretionary fiscal policy in a low interest rate environment. Technical report, National Bureau of Economic Research.

Green, D., B. Melzer, J. A. Parker, and R. Pfirrmann-Powell (2014). Accelerator or brake? Microeconomic estimates of the $\dddot{i}_{i} \frac{1}{2}$ cash for clunkersi $\measuredangle \frac{1}{2}$ and aggregate demand. Unpublished Manuscript, MIT.

Hall, R. and S. Woodward (2008, December 11). Measuring the effect of infrastructure spending on GDP, Financial Crisis and Recession (blog).

Hall, R. E. (2011). The long slump. American Economic Review 101 (2), 431-469.

Hausman, J. K. and J. F. Wieland (2014). Abenomics: Preliminary analysis and outlook. Brookings Papers on Economic Activity, 1-63.

Hurd, M. D. and S. Rohwedder (2012). Measuring total household spending in a monthly internet survey: Evidence from the American Life Panel. Technical report, National Bureau of Economic Research.

Ichiue, H. and S. Nishiguchi (2015). Inflation expectations and consumer spending at the zero bound: Micro evidence. Economic Inquiry 53(2), 1086-1107.

Jalil, A. and G. Rua (2016). Inflation expectations and recovery from the depression in 1933: Evidence from the narrative record. Explorations in Economic History, forthcoming.

Jappelli, T. and L. Pistaferri (2010). The consumption response to income changes. Annual Review of Economics 2, 479-506.

Jappelli, T. and L. Pistaferri (2014). Fiscal policy and MPC heterogeneity. American Economic Journal: Macroeconomics 6(4), 107-136.

Jonung, L. (1981). Perceived and expected rates of inflation in Sweden. The American Economic Review 71(5), 961-968.

Krugman, P. R. (1998). It's baaack: Japan's slump and the return of the liquidity trap. Brookings Papers on Economic Activity 1998(2), 137-205.

McKay, A., E. Nakamura, and J. Steinsson (2015). The power of forward guidance revisited. Technical report, National Bureau of Economic Research.

Menz, J.-O. and P. Poppitz (2013). Household disagreement on inflation expectations and socioeconomic media exposure in Germany. Unpublished Manuscript, Deutsche Bundesbank. 
Mian, A. and A. Sufi (2011). House prices, home equity-based borrowing, and the US household leverage crisis. American Economic Review 101 (5), 2132-2156.

Mian, A. and A. Sufi (2012). The effects of fiscal stimulus: Evidence from the 2009 cash for clunkers program. The Quarterly Journal of Economics 127(3), 1107-1142.

Nakamura, E., J. Steinsson, P. Sun, and D. Villar (2016). The elusive costs of inflation: Price dispersion during the US great inflation. Unpublished Manuscript, Columbia University.

Poterba, J. M. (1996). Retail price reactions to changes in state and local sales taxes. National Tax Journal 49(2), 165-176.

Romer, C. D. and D. H. Romer (2010). The macroeconomic effects of tax changes: Estimates based on a new measure of fiscal shocks. The American Economic Review $100(3), 763-801$.

Romer, C. D. and D. H. Romer (2013). The missing transmission mechanism in the monetary explanation of the Great Depression. The American Economic Review 103(3), 66-72.

Shapiro, M. D. (1991). Economic stimulant. Technical report, New York Times.

SPD (2005). Vertrauen in Deutschland. Das Wahlmanifest der SPD. Electoral Manifest.

Stehle, R. M. (2006, June 23, 2006). Geplante Mehrwertsteuer-Anhebung treibt Inflation. Berliner Zeitung.

Weber, A. (2006, June 23, 2006). Weber haelt Zinserhoehung der EZB fuer notwendig. Handelsblatt.

Werning, I. (2012). Managing a liquidity trap: Monetary and fiscal policy. Unpublished Manuscript, MIT.

Wiederholt, M. (2016). Empirical properties of inflation expectations and the zero lower bound. Unpublished Manuscript, Goethe University Frankfurt.

Woodford, M. (2011). Simple analytics of the government expenditure multiplier. American Economic Journal: Macroeconomics 3(1), 1-35. 
Figure 2: Expected Increase in Inflation and Average Readiness to Spend on Durables

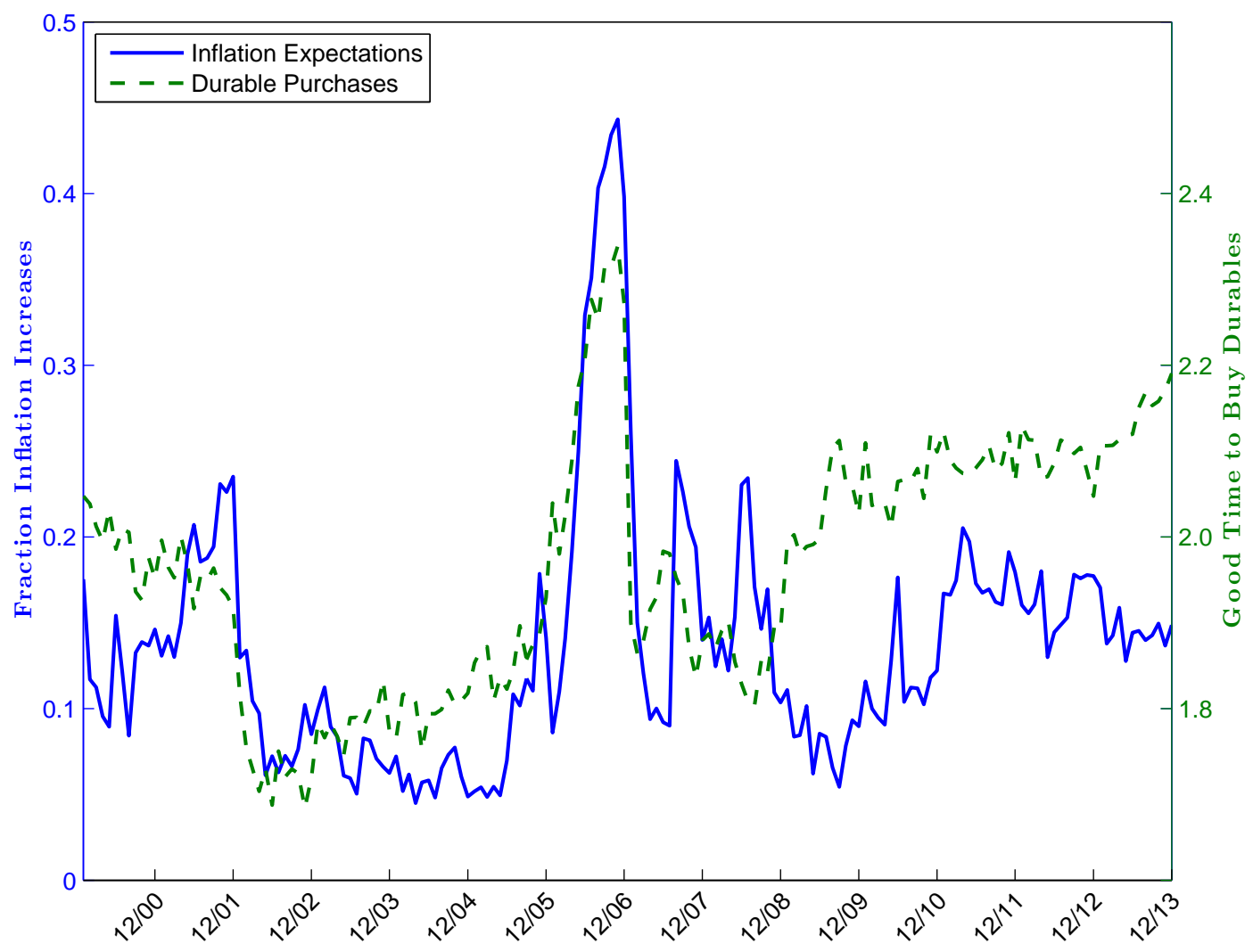

This figure plots average monthly inflation expectation (blue line, left y-axis) and the average monthly readiness to purchase durables (green dashed line, right y-axis) over time. We use the confidential micro data underlying the GfK Consumer Climate MAXX survey to construct these variables. GfK asks a representative sample of 2,000 households how consumer prices will evolve in the next twelve months compared to the previous twelve months and whether it is a good time to purchase durables given the current economic conditions. We create a dummy variable which equals 1 when a household expects inflation to increase. Higher values correspond to better times to purchase durables. The sample period is January 2000 to December 2013 for a total of fourteen years. 
Figure 3: Standardized Lagged Inflation Expectations and Durable Inflation Rate

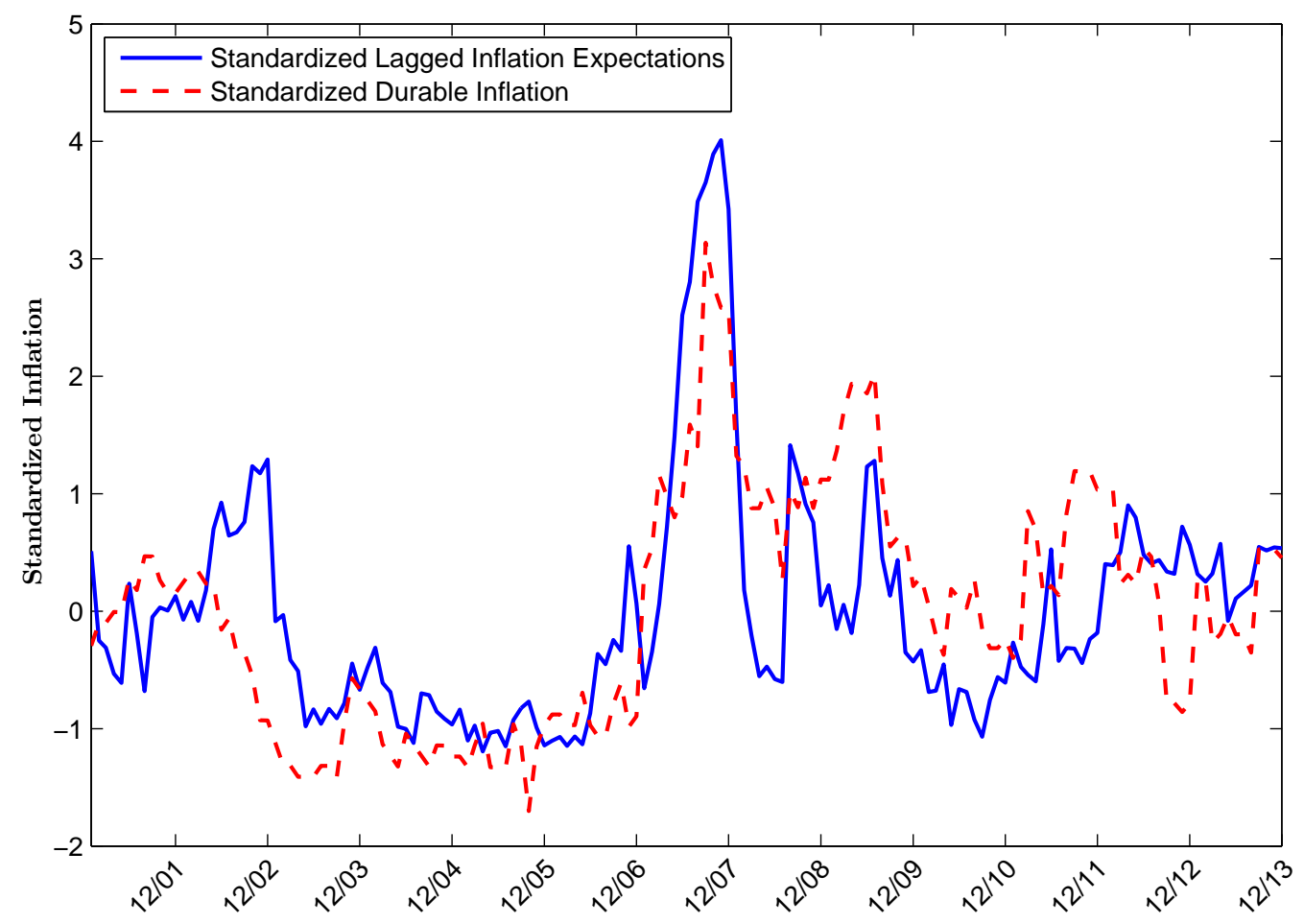

This figure plots the monthly time series of the one-year lagged standardized average monthly inflation expectation and the harmonized major durables consumer price inflation rate in percent at an annual rate. We use the confidential micro data underlying the GfK Consumer Climate MAXX survey to construct inflation expectations. GfK asks a representative sample of 2,000 households how consumer prices will evolve in the next twelve months compared to the previous twelve months. We create a dummy variable which equals 1 when a household expects inflation to increase. The sample period is January 2000 to December 2013 for a total of fourteen years. 


\section{Figure 4: Expected Increase in Inflation: Germany and European Union}

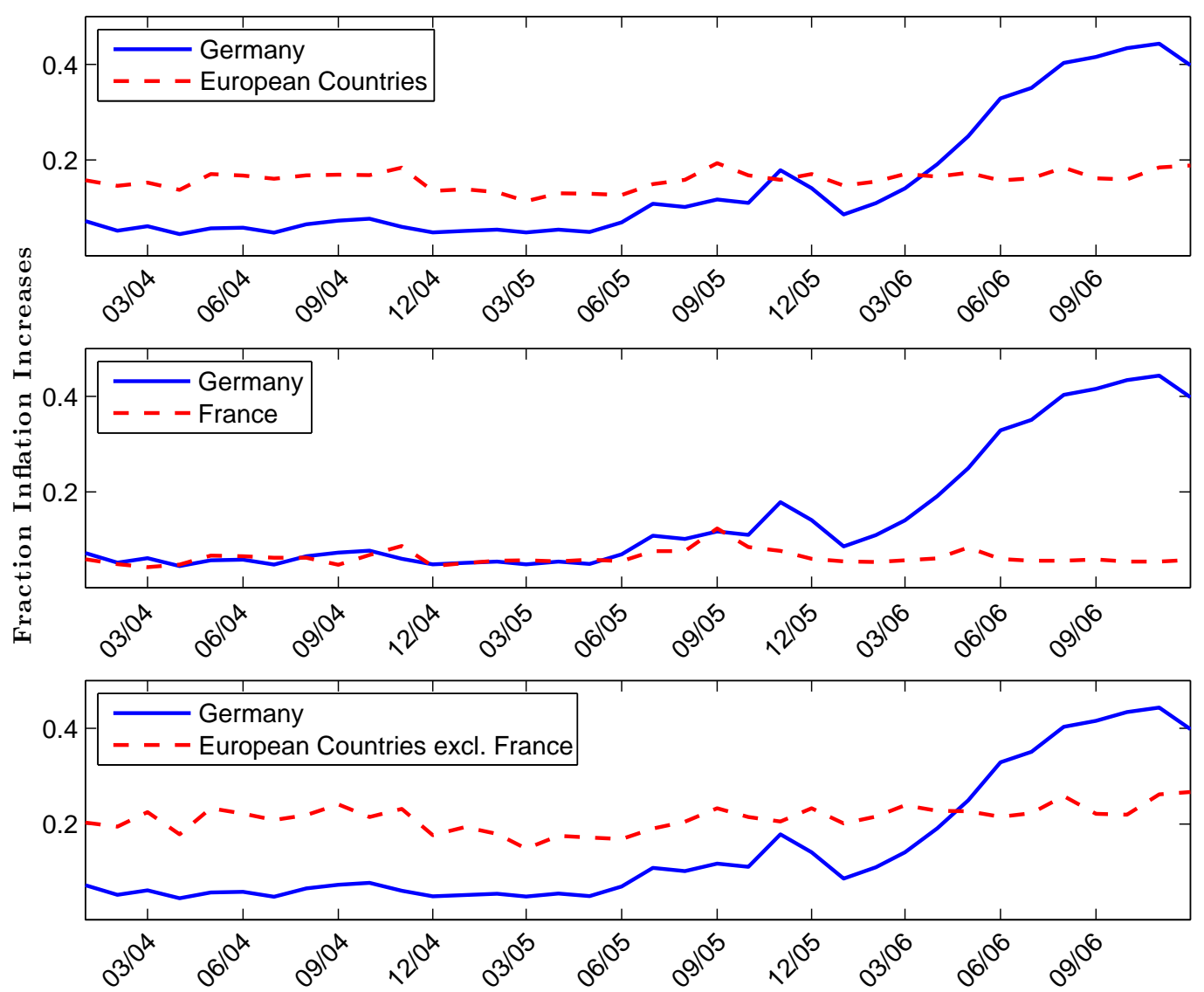

This figure plots average monthly inflation expectation over time. We use the confidential micro data underlying the GfK Consumer Climate MAXX survey to construct the variables for Germany and similar data from national statistical agencies and GfK subsidiaries for the United Kingdom, Sweden, and France. GfK asks a representative sample of 2,000 households how consumer prices will evolve in the next twelve months compared to the previous twelve months. We create a dummy variable which equals 1 when a household expects inflation to increase. The sample period is January 2004 to December 2006 for a total of three years. 


\section{Figure 5: Readiness to Spend on Durables: Germany and European Union}

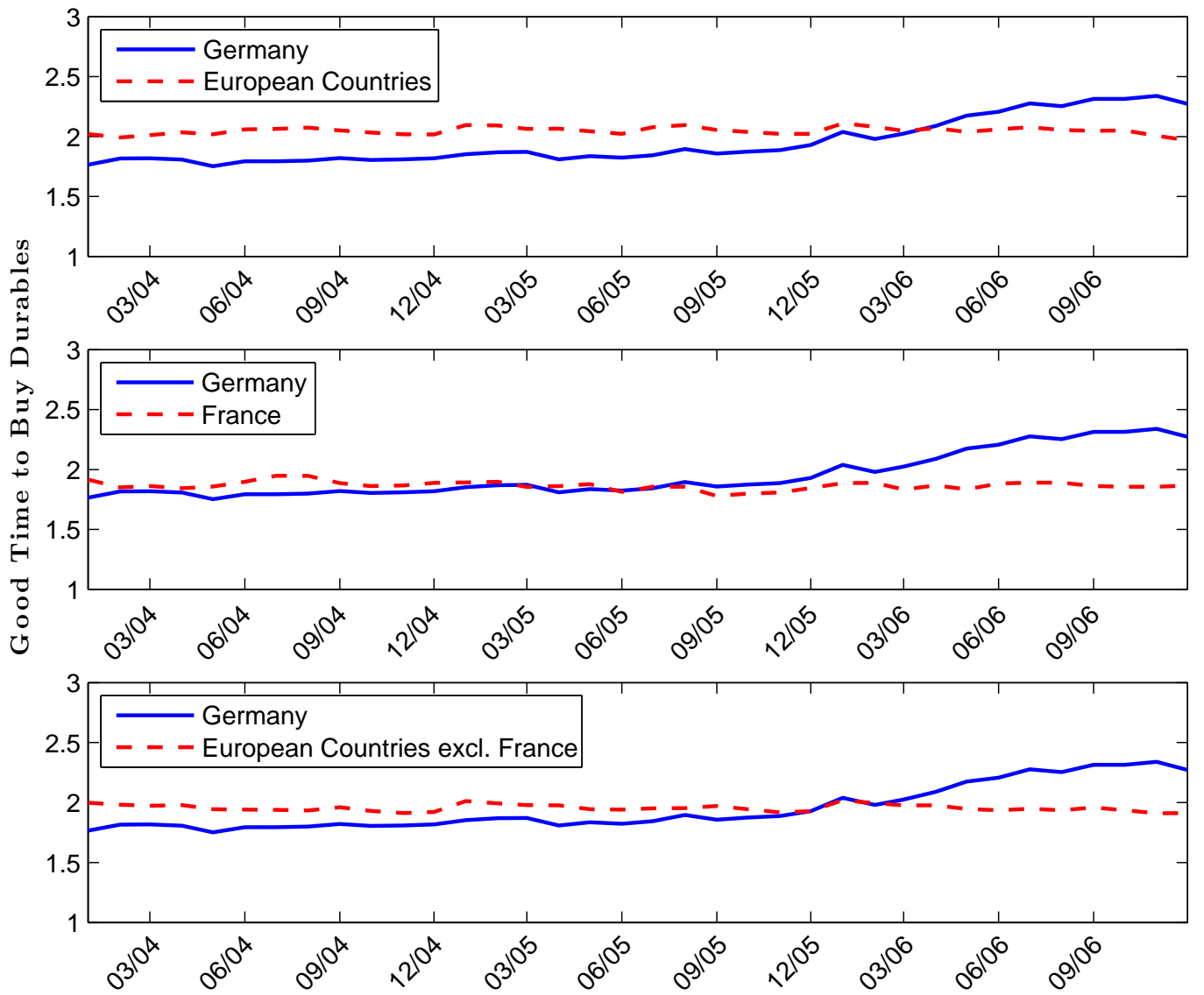

This figure plots the average monthly readiness to purchase durables over time. We use the confidential micro data underlying the GfK Consumer Climate MAXX survey to construct these variables for Germany and similar data from national statistical agencies and GfK subsidiaries for the United Kingdom, Sweden, and France. GfK asks a representative sample of 2,000 households whether it is a good time to purchase durables given the current economic conditions. Higher values correspond to better times to purchase durables. The sample period is January 2004 to December 2006 for a total of three years. 
Figure 6: Common Support of Treated and Matched Households

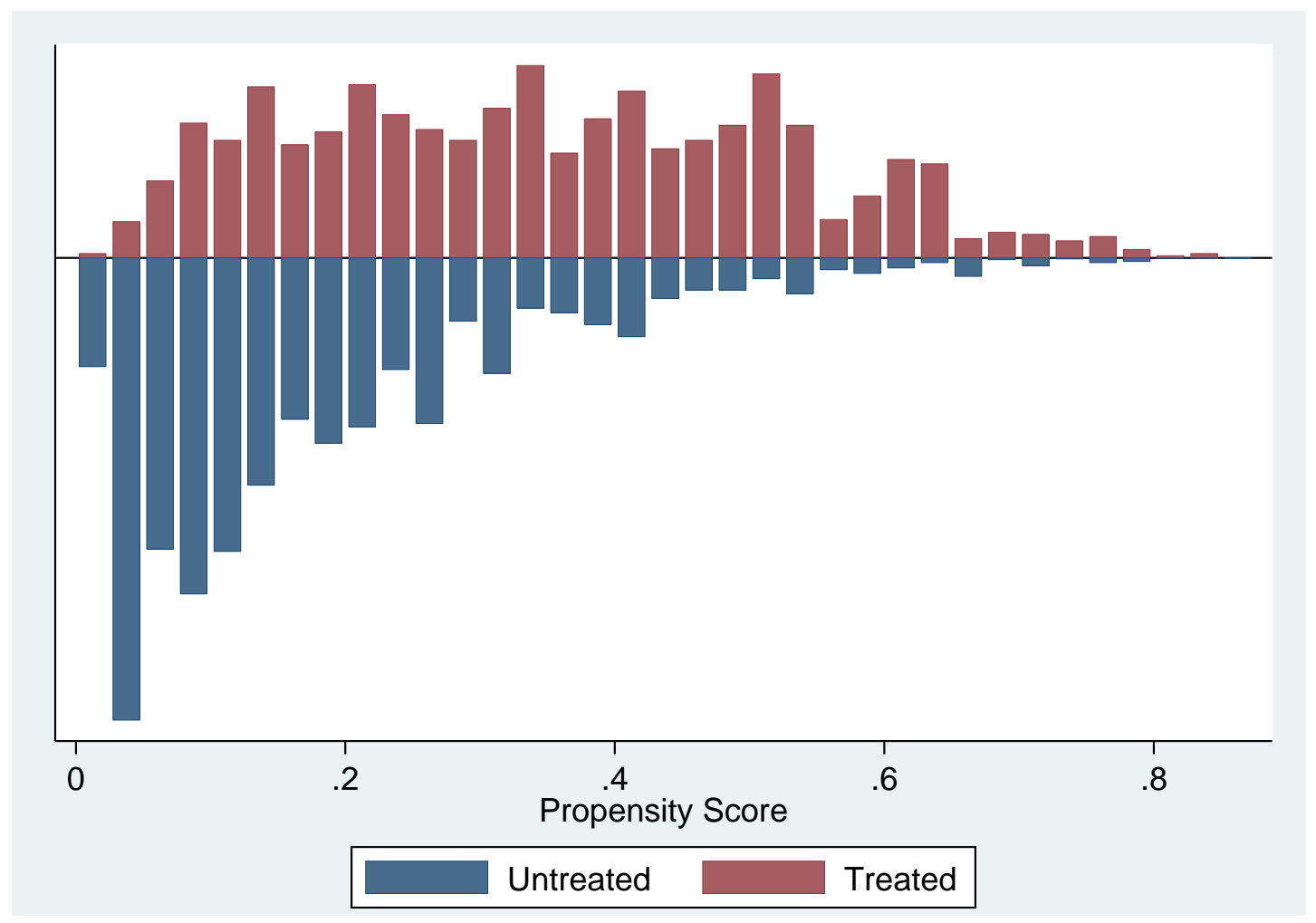

This figure plots the number of households in the untreated (blue) and treated (red) group across forty equal-length partitions of the distribution of the propensity score in the baseline month (June 2005) for the difference-in-differences analysis. We estimate the propensity score with a logit specification whose outcome variable is the indicator for whether a household is in the treated or control group, and the controls are the observables we use for the matching of households: age group, gender, education group, income group, and social status group. The treated group includes 1,431 German households, whereas the control group includes 5,108 households from the UK, France, and Sweden. 
Figure 7: Household Expectations

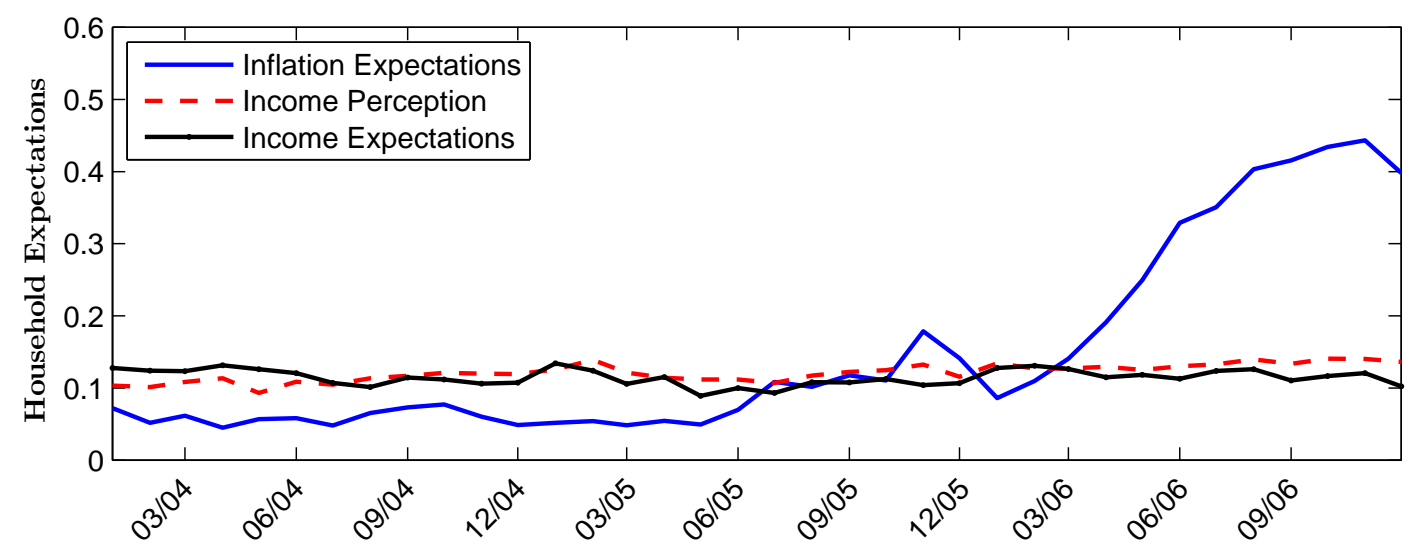

This figure plots average monthly inflation expectation, perception of past income, and expectation of future income over time. We use the confidential micro data underlying the GfK Consumer Climate MAXX survey to construct those variables. GfK asks a representative sample of 2,000 households how consumer prices will evolve in the next twelve months compared to the previous twelve months, how the financial situation of the household evolved during the past twelve months, and how the financial situation of the household will evolve during the next twelve months. We create a dummy variable which equals 1 when a household expects inflation to increase, perceives an improved financial situation, and expects an improved financial situation. The sample period is January 2004 to December 2006 for a total of three years. 
Figure 8: Real Aggregate Consumption Growth

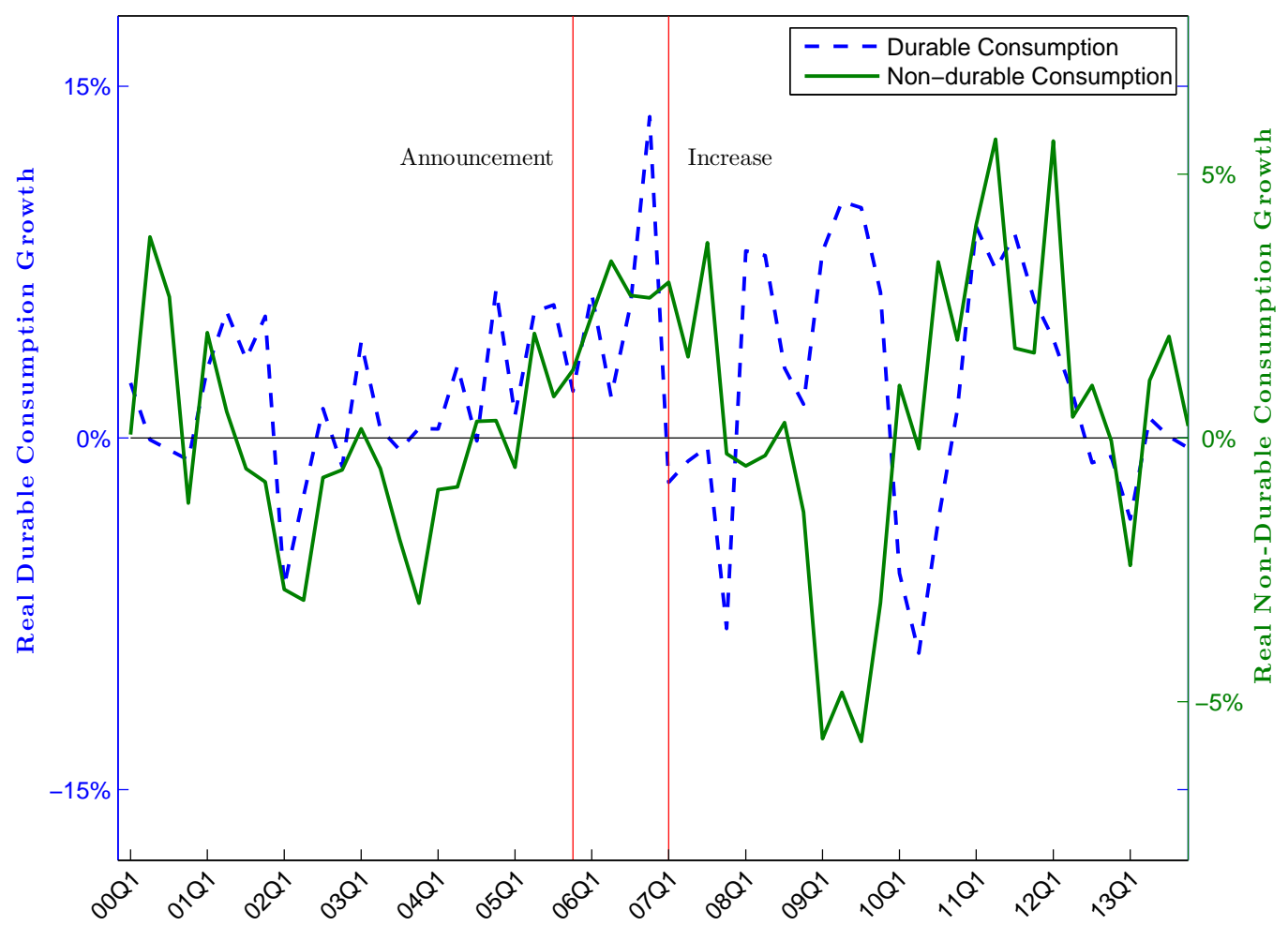

This figure plots real durable (blue dashed line, left y-axis) and non-durable (green line, right y-axis) consumption growth at the quarterly frequency from the German statistical office Destatis. The sample period is the first quarter of 2000 to the fourth quarter of December 2013 for a total of fourteen years. 
Figure 9: Change in the Readiness to Spend on Durables for German vs. Foreign Households

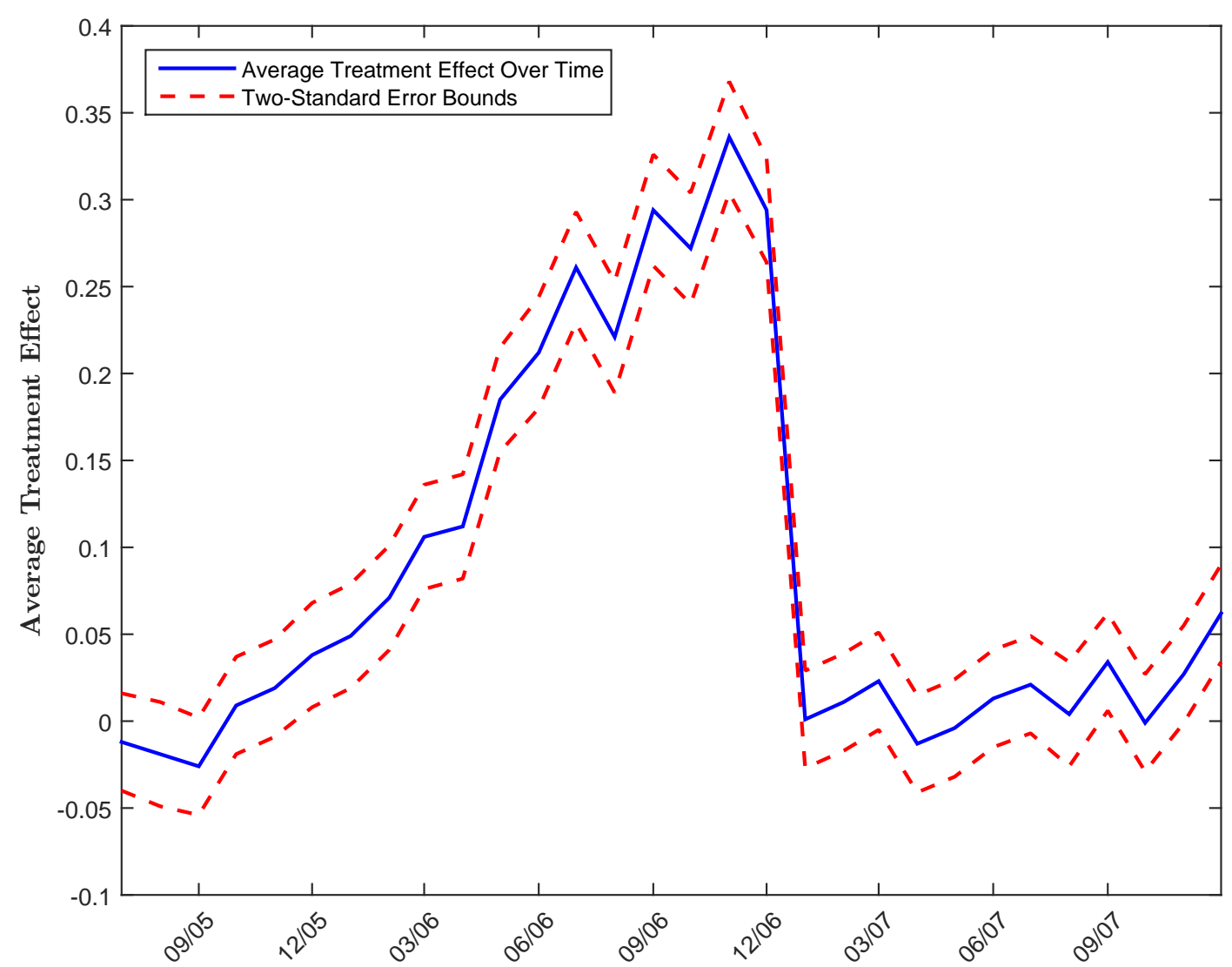

This figure plots $\beta_{m}$ coefficient (solid line) of $\Delta$ Dur $_{i, 06 / 2005 \rightarrow m}=\alpha+\beta_{m} \times V$ ATshock $k_{i}+\Delta X_{i, 06 / 2005 \rightarrow m}^{\prime} \times \gamma+$ $\epsilon_{i}$ and two standard deviation error bands (dashed line). $\Delta D$ ur $_{i, 06 / 2005 \rightarrow m}$ is the difference in the willingness to spend on durable goods between month $m$ and June 2005, VATshock $k_{i}$ is an indicator which equals 1 if the household was exposed to the VAT shock, $\beta_{m}$ captures the effect of the VAT shock on the willingness to buy durables for household $i$ in month $m$, and $\Delta X_{i, 06 / 2005 \rightarrow m}^{\prime}$ is the difference in a set of observables between month $m$ and the baseline month. We use the micro data underlying the Directorate-General for Economic and Financial Affairs of the European Commission harmonized consumer surveys to construct these variables. 


\section{Table 1: Descriptive Statistics}

This table reports descriptive statistics for households' inflation expectations and readiness to purchase durables in Panel A, household demographics in Panel B, household expectations and perceptions in Panel C, and macroeconomics aggregates in Panel D. We use the confidential micro data underlying the GfK Consumer Climate survey to measure the variables in Panel A to Panel C. GfK asks a representative sample of 2,000 households questions about general economic expectations, income expectations, and willingness to buy in order to create an aggregate measure labeled "consumer climate." For Panel A, GfK asks whether it is a good time to purchase durables given the current economic conditions. GfK also asks how consumer prices will evolve in the next twelve months compared to the previous twelve months. Inflation increase is a dummy variable which equals 1 when a household replies that inflation will increase. GfK also asks how consumer prices evolved in the previous twelve months. See the online appendix for data sources and detailed data definitions. The sample period is January 2000 to December 2013.

\begin{tabular}{|c|c|c|c|c|c|c|c|c|c|}
\hline & & Nobs & Mean & Std & Min & $\mathrm{p} 25$ & p50 & p75 & Max \\
\hline \multicolumn{10}{|c|}{ Panel A: Inflation expectations and readiness to spend } \\
\hline Readiness to buy durables & $\begin{array}{l}\text { Good time } \\
\text { Neither } \\
\text { Bad time }\end{array}$ & 326,011 & $\begin{array}{l}20.26 \% \\
56.15 \% \\
23.59 \%\end{array}$ & & & & & & \\
\hline Inflation increase & & 355,400 & $13.77 \%$ & 0.34 & 0 & 0 & 0 & 0 & 1 \\
\hline Inflation perception & $\begin{array}{l}\text { increased substantially } \\
\text { increased somewhat } \\
\text { increased slightly } \\
\text { remained the same } \\
\text { decreased }\end{array}$ & 348,521 & $\begin{array}{r}28.06 \% \\
29.69 \% \\
27.80 \% \\
13.23 \% \\
1.23 \%\end{array}$ & & & & & & \\
\hline \multicolumn{10}{|c|}{ Panel B: Household demographics } \\
\hline Sex & $\begin{array}{l}\text { Male } \\
\text { Female }\end{array}$ & 355,400 & $\begin{array}{l}53.83 \% \\
46.17 \%\end{array}$ & & & & & & \\
\hline Age & & 355,400 & 46.07 & 17.49 & 14 & 33 & 45 & 60 & 99 \\
\hline Education & $\begin{array}{l}\text { Hauptschule } \\
\text { Realschule } \\
\text { Gymnasium } \\
\text { Universitaet }\end{array}$ & 350,093 & $\begin{array}{r}42.74 \% \\
38.96 \% \\
10.34 \% \\
7.97 \%\end{array}$ & & & & & & \\
\hline Household members & & 355,400 & 2.49 & 1.17 & 1 & 2 & 2 & 3 & 5 \\
\hline$x^{2}$ & $\begin{array}{l}\text { City }<9,999 \\
9,999<=\text { City }<49,999 \\
50,000<=\text { City }<199,999 \\
199,999<=\text { City }\end{array}$ & 355,400 & $\begin{array}{l}28.24 \% \\
34.46 \% \\
15.66 \% \\
21.64 \%\end{array}$ & & & & & & \\
\hline Kids at home & $\begin{array}{l}\text { yes } \\
\text { no }\end{array}$ & 355,400 & $\begin{array}{l}26.88 \% \\
73.12 \%\end{array}$ & & & & & & \\
\hline Number of kids & & 352,256 & 0.42 & 0.78 & 0 & 0 & 0 & 1 & 4 \\
\hline Net income (inc) & $\begin{array}{l}\text { inc }<1,000 \\
1,000<=\text { inc }<1,500 \\
1,500<=\text { inc }<2,500 \\
2,500<=\text { inc }\end{array}$ & 270,592 & $\begin{array}{r}43.60 \% \\
28.66 \% \\
20.81 \% \\
6.93 \%\end{array}$ & & & & & & \\
\hline \multicolumn{10}{|c|}{ Panel C: Household expectations and perceptions } \\
\hline Past Financial situation & $\begin{array}{l}\text { Improved substantially } \\
\text { Improved somewhat } \\
\text { Identical } \\
\text { Worsened somewhat } \\
\text { Worsened substantially }\end{array}$ & 351,486 & $\begin{array}{l}0.02 \\
0.12 \\
0.61 \\
0.21 \\
0.05\end{array}$ & & & & & & \\
\hline Financial outlook & $\begin{array}{l}\text { Improves substantially } \\
\text { Improves somewhat } \\
\text { Identical } \\
\text { Worsens somewhat } \\
\text { Worsens substantially }\end{array}$ & 341,105 & $\begin{array}{l}0.01 \\
0.11 \\
0.73 \\
0.13 \\
0.02\end{array}$ & & & & & & \\
\hline Current financial situation & $\begin{array}{l}\text { Save a lot } \\
\text { Save little } \\
\text { Don't save } \\
\text { Dissave } \\
\text { Take on debt }\end{array}$ & 345,683 & $\begin{array}{l}0.04 \\
0.39 \\
0.41 \\
0.13 \\
0.02\end{array}$ & & & & & & \\
\hline Expected unemployment rate & $\begin{array}{l}\text { Increases substantially } \\
\text { Increases somewhat } \\
\text { Identical } \\
\text { Decreases somewhat } \\
\text { Decreases a lot }\end{array}$ & 342,563 & $\begin{array}{r}14.10 \\
32.24 \\
35.28 \\
17.27 \\
1.12\end{array}$ & & & & & & \\
\hline
\end{tabular}


Table 1: Descriptive Statistics continued

Continued from previous page.

\begin{tabular}{|c|c|c|c|c|c|c|c|c|}
\hline & Nobs & Mean & Std & Min & $\mathrm{p} 25$ & $\mathrm{p} 50$ & $\mathrm{p} 75$ & $\operatorname{Max}$ \\
\hline \multicolumn{9}{|c|}{ Panel D: Macroeconomic aggregates } \\
\hline CPI Inflation & 355,400 & $1.61 \%$ & $0.65 \%$ & $-0.50 \%$ & $1.21 \%$ & $1.64 \%$ & $1.98 \%$ & $3.27 \%$ \\
\hline Unemployment rate & 355,400 & 8.99 & 1.61 & 6.40 & 7.60 & 9.00 & 10.30 & 12.70 \\
\hline European Uncertainty Index & 355,400 & 134.25 & 62.78 & 46.61 & 83.54 & 116.53 & 170.93 & 331.54 \\
\hline German Uncertainty Index & 355,400 & 119.79 & 57.60 & 28.43 & 79.13 & 106.68 & 144.33 & 377.84 \\
\hline MRO rate & 355,400 & 3.09 & 1.53 & 0.25 & 1.00 & 4.25 & 4.25 & 4.25 \\
\hline Dax & 355,400 & 5840 & 1511 & 2424 & 4769 & 5970 & 6949 & 9552 \\
\hline Volatility DAX & 355,400 & 22.79 & 8.67 & 11.24 & 16.88 & 20.62 & 25.91 & 57.96 \\
\hline Industrial Production Growth & 355,400 & $1.60 \%$ & $6.97 \%$ & $-27.25 \%$ & $0.00 \%$ & $2.41 \%$ & $5.65 \%$ & $14.55 \%$ \\
\hline
\end{tabular}

This table reports the average marginal effects of a multinomial logit regression. Households' readiness to purchase durables is the dependent variable. Inflation increase is a dummy variable which equals 1 when a household replies that inflation will increase. Past inflation measures the household perception of the increase in consumer prices during the last twelve months. We also control for household demographics, household expectations, and contemporaneous macroeconomic variables where indicated. We use the confidential micro data underlying the GfK Consumer Climate MAXX survey to construct these variables. GfK asks a representative sample of 2,000 households on a monthly basis whether it is a good time to purchase durables given the current economic conditions. Households can reply that it is a good time, it is a bad time, or it is neither a good time nor a bad time. Standard errors are clustered at the quarter level (56 clusters). The sample period is January 2000 to December 2013.

(1)

Inflation expectation

$0.0624^{* * *}$

(0.0162)

Past Inflation
(2)

$0.0749^{* * *}$

(0.0152)

$-0.0342^{* * *}$

(0.0028)
(3)

$0.0755^{* * *}$

(0.0156)

$-0.0300^{* * *}$

(0.0030)
(4)

$0.0888^{* * *}$

(0.0160)

$-0.0200^{* * *}$

(0.0035)
(5)

$0.0875^{* *}$

$(0.0116)$

$-0.0114^{* * *}$

(0.0023)
Demographics

Individual expectations

Macro aggregates

Pseudo $\mathrm{R}^{2}$

Nobs

Standard errors in parentheses

$* p<0.10, * * p<0.05, * * * p<0.01$

$\begin{array}{ccc}\mathrm{X} & \mathrm{X} & \mathrm{X} \\ & \mathrm{X} & \mathrm{X} \\ & & \mathrm{X} \\ 0.0292 & 0.0654 & 0.0762 \\ 44,497 & 219,799 & 219,799\end{array}$

0.0031

0.0161

244,497

219,799 


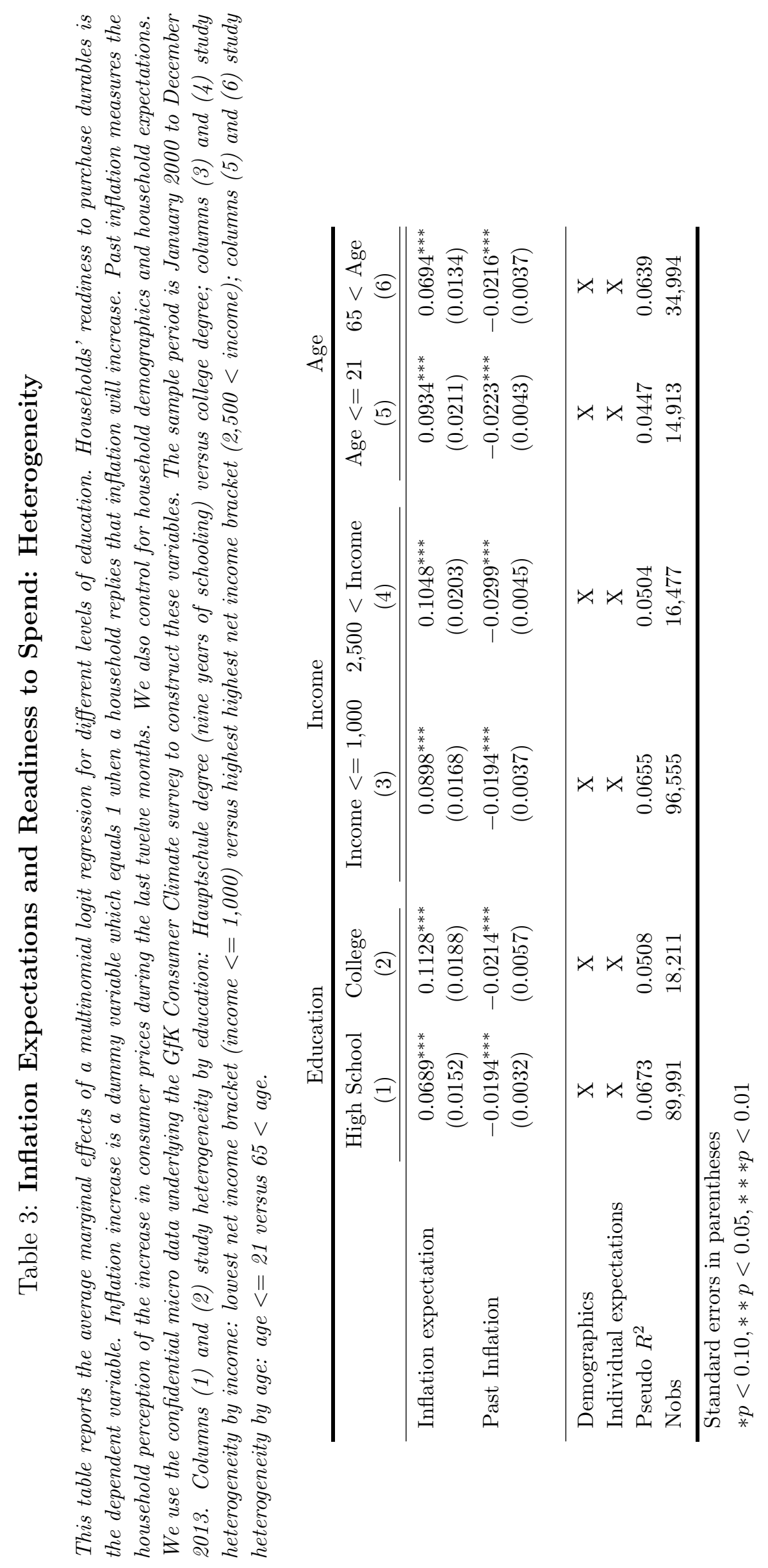




\section{Table 4: Inflation Expectations and Readiness to Spend: matched sample}

This table reports the average marginal effects of a multinomial logit regression. Households' readiness to purchase durables is the dependent variable. Inflation increase is a dummy variable which equals 1 when a household replies that inflation will increase. Past inflation measures the household perception of the increase in consumer prices during the last twelve months. We use the confidential micro data underlying the Directorate-General for Economic and Financial Affairs of the European Commission harmonized consumer surveys to construct these variables. The surveys ask representative samples of households on a monthly basis whether it is a good time to purchase durables given the current economic conditions. Households can reply that it is a good time, it is a bad time, or it is neither a good time nor a bad time. In this table we study the "it is a good time" outcome. Standard errors are clustered at the quarter level. The sample period is January 2004 to December 2012 for France, Sweden, and the United Kingdom. The sample period is January 2004 to October 2005 and January 2007 to December 2012. We use the longest sample for which we have data on all countries.

\begin{tabular}{lcccc}
\hline & & & & Germany excl \\
& France & Sweden & UK & VAT period \\
& $(1)$ & $(2)$ & $(3)$ & $(4)$ \\
\hline Inflation expectation & $0.0265^{* * *}$ & $0.0265^{* * *}$ & $0.0402^{* * *}$ & $0.0555^{* * *}$ \\
& $(0.0037)$ & $(0.0049)$ & $(0.0067)$ & $(0.0037)$ \\
Past Inflation & $-0.0163^{* * *}$ & $-0.0438^{* * *}$ & $-0.0294^{* * *}$ & $-0.0140^{* * *}$ \\
& $(0.0015)$ & $(0.0051)$ & $(0.0019)$ & $(0.0039)$ \\
& & & & $\mathrm{X}$ \\
Demographics & $\mathrm{X}$ & $\mathrm{X}$ & $\mathrm{X}$ & $\mathrm{X}$ \\
Individual expectations & $\mathrm{X}$ & $\mathrm{X}$ & $\mathrm{X}$ & 0.0641 \\
Pseudo R & 0.0445 & 0.0317 & 0.0446 & 125,407 \\
Nobs & 163,419 & 141,903 & 87,864 & \\
\hline Standard & & & &
\end{tabular}

Standard errors in parentheses

$* p<0.10, * * p<0.05, * * * p<0.01$ 


\section{Table 5: Balancing of Variables - German and Foreign Households (June 2005)}

This table describes the balancing of the observables we use to match treated and control households in the baseline month (June 2005) for the difference-in-differences analysis. For each variable, the first column reports the mean within the pool of control households (UK, France, and Sweden). The second column reports the mean within the pool of treated German households. The third and fourth column report the results for a two-sided t-test whose null hypothesis is that the means across groups are equal. The two pools are constituted by 1,431 households (treated) and 5,108 households (control) that overlap on the same common support.

\begin{tabular}{lcccc}
\hline Variable & Mean Control & Mean Treated & t-stat & p-value \\
\hline Age (four groups) & 2.33 & 2.30 & 1.01 & 0.31 \\
Male & 0.47 & 0.47 & 0.22 & 0.82 \\
Education (three groups) & 1.77 & 1.81 & -1.15 & 0.25 \\
Income (four quartiles) & 2.31 & 2.28 & 0.8 & 0.42 \\
Social Status (three groups) & 2.60 & 2.61 & -0.37 & 0.71 \\
& & & & \\
\hline Obs in common support & 5,108 & 1,431 & & \\
\hline
\end{tabular}




\section{Table 6: Inflation Expectations and Readiness to Save}

This table reports the average marginal effects of a multinomial logit regression. Households' readiness to save is the dependent variable. Inflation expectation is a dummy variable which equals 1 when a households replies that inflation will increase. Past inflation measures the household perception of the increase in consumer prices during the last twelve months. We use the confidential micro data underlying the GfK Consumer Climate survey to construct these variables. The sample period is January 2000 to December 2013.

\begin{tabular}{lccc}
\hline & $\begin{array}{c}\text { Not at all } \\
(1)\end{array}$ & $\begin{array}{c}\text { Not really } \\
(2)\end{array}$ & $\begin{array}{c}\text { Good time } \\
(3)\end{array}$ \\
\hline Inflation increase & $0.0160 * * *$ & $0.0082 * *$ & 0.0006 \\
& $(0.0016)$ & $(0.0036)$ & $(0.0082)$ \\
Past Inflation & $0.0019 * *$ & $-0.0134 * * *$ & $0.0332 * * *$ \\
& $(0.0007)$ & $(0.0023)$ & $(0.0045)$ \\
& & & \\
\hline Demographics & $\mathrm{X}$ & $\mathrm{X}$ & $\mathrm{X}$ \\
Individual expectations & $\mathrm{X}$ & $\mathrm{X}$ & $\mathrm{X}$ \\
Pseudo R & & 0.0203 & \\
Nobs & & 234,522 & \\
\hline Standard & &
\end{tabular}

Standard errors in parentheses

$* p<0.10, * * p<0.05, * * * p<0.01$ 


\title{
Online Appendix: Inflation Expectations and Consumption Expenditure
}

\author{
Francesco D'Acunto, Daniel Hoang, and Michael Weber
}

Not for Publication

\section{Survey Questions}

Below we report the original survey questions with answer choices for Germany, the English translation, and the harmonized surveys from the Directorate-General for Economic and Financial Affairs of the European Commission harmonized consumer surveys used in Section IV for the matching estimator.

\section{A. Germany}

Question 1 Wie hat sich Ihrer Meinung nach die "allgemeine Wirtschaftslage" in Deutschland in den letzten 12 Monaten entwickelt?

Sie ...

- hat sich wesentlich verbessert

- hat sich etwas verbessert

- ist in etwa gleich geblieben

- hat sich etwas verschlechtert

- hat sich wesentlich verschlechtert

- weiss nicht

Question 2 Wie haben sich Ihrer Ansicht nach die Verbraucherpreise in den letzten 12 Monaten entwickelt?

Sie sind $\ldots$

- stark gestiegen

- in Massen gestiegen

- leicht gestiegen

- in etwa gleich geblieben

- gesunken

- weiss nicht

Question 3 Wie werden sich Ihrer Ansicht nach die Verbraucherpreise in den kommenden 12 Monaten im Vergleich zu den letzten 12 Monaten entwickeln?

Sie werden ... 
- staerker als bisher steigen

- etwa im gleichen Masse wie bisher steigen

- weniger stark als bisher steigen

- in etwa gleich bleiben

- gesunken

- weiss nicht

Question 4 Wie hat sich die finanzielle Lage Ihres Haushaltes in den letzten 12 Monaten entwickelt?

Sie ...

- hat sich wesentlich verbessert

- hat sich etwas verbessert

- ist in etwa gleichgeblieben

- hat sich etwas verschlechtert

- hat sich wesentlich verschlechtert

- weiss nicht

Question 5 Wie wird sich Ihrer Ansicht nach die finanzielle Lage Ihres Haushaltes in den kommenden 12 Monaten entwickeln?

Sie wird ...

- sich wesentlich verbessern

- sich etwas verbessern

- in etwa gleichbleiben

- sich etwas verschlechtern

- sich wesentlich verschlechtern

- weiss nicht

Question 6 Wie wird sich Ihrer Ansicht nach die allgemeine Wirtschaftslage in Deutschland in den kommenden 12 Monaten entwickeln?

Sie wird ...

- sich wesentlich verbessern

- sich etwas verbessern

- in etwa gleichbleiben

- sich etwas verschlechtern

- sich wesentlich verschlechtern

- weiss nicht

Question 7 Wie ist die derzeitige finanzielle Lage Ihres Haushaltes?

- wir sparen viel

- wir sparen ein wenig

- wir kommen mit unseren finanziellen Mitteln so gerade aus

- wir greifen etwas unsere Ersparnisse an

- wir verschulden uns 
- weiss nicht

Question 8 Glauben Sie, dass es in Anbetracht der allgemeinen Wirtschaftslage derzeit guenstig ist, groessere Anschaffungen (Moebel, elektrische/elektronische Geraete usw.) zu taetigen?

- ja, jetzt der Augenblick ist guenstig

- der Augenblick ist weder besonders guenstig noch besonders unguenstig

- nein, der Augenblick ist nicht guenstig

- weiss nicht

Question 10 Wie wird sich Ihrer Ansicht nach die Zahl der Arbeitslosen in Deutschland in den kommenden 12 Monaten entwickeln?

Die Zahl wird ...

- stark steigen

- leicht steigen

- in etwa gleich bleiben

- leicht zurueckgehen

- stark zurueckgehen

- weiss nicht

Question 11 Wollen Sie in den kommenden 12 Monaten fuer groessere Anschaffungen (Moebel, elektrische /elektronische Geraete usw.) mehr oder weniger ausgeben als in den letzten 12 Monaten?

Ich werde ...

- wesentlich mehr ausgeben

- etwas mehr ausgeben

- in etwa gleich viel ausgeben

- etwas weniger ausgeben

- wesentlich weniger ausgeben

- weiss nicht

Question 12 Wie wahrscheinlich ist es, dass Sie in den kommenden 12 Monaten Geld sparen werden?

- sehr wahrscheinlich

- recht wahrscheinlich

- unwahrscheinlich

- sehr unwahrscheinlich

- weiss nicht

Question 13 Glauben Sie, dass es in Anbetracht der allgemeinen Wirtschaftslage derzeit ratsam ist, zu sparen?

- ja, auf alle Faelle

- wahrscheinlich ja 
- eher nicht

- auf keinen Fall

- weiss nicht

Question 1 How did you perceive the general economic situation in Germany over the last 12 months?

It ...

- improved substantially

- improved somewhat

- remained about the same

- worsened somewhat

- worsened substantially

- don't know

Question 2 What is your perception on how consumer prices evolved during the last 12 months?

They ...

- increased substantially

- increased somewhat

- increased slightly

- remained about the same

- decreased

- don't know

Question 3 How will consumer prices evolve during the next 12 months compared to the previous 12 months?

They will ...

- increase more

- increase the same

- increase less

- stay the same

- decrease

- don't know

Question 4 How did the financial situation of your household evolve during the past 12 months?

It ...

- improved substantially

- improved somewhat

- remained about the same

- worsened somewhat

- worsened substantially 
- don’t know

Question 5 How will the financial situation of your household evolve during the next 12 months?

It will ...

- improve substantially

- improve somewhat

- remain the same

- worsen slightly

- worsen substantially

- don't know

Question 6 How will the general economic situation in Germany evolve during the next 12 months?

It will ...

- improve substantially

- improve slightly

- remain the same

- worsen slightly

- worsen substantially

- don't know

Question 7 What is the current financial situation of your household?

- we save a lot

- we save a bit

- we just manage to live from our financial inflows and don't save

- we have to de-save

- we become indebted

- don't know

Question 8 Given the current economic situation, do you think it's a good time to buy larger items such as furniture, electronic items etc?

- yes, it's a good time

- the time is neither good nor bad

- no, it's a bad time

- don't know

Question 10 What is your expectation regarding the number of unemployed people in Germany in the next 12 months?

It will ...

- increase substantially

- increase somewhat 
- remain the same

- decrease somewhat

- decrease a lot

- don't know

Question 11 Do you plan to spend more money during the next 12 months on larger items such as furniture, electronics, etc compared to the previous 12 months?

I will ...

- spend substantially more

- spend somewhat more

- spend about the same

- spend somewhat less

- spend substantially less

- don't know

Question 12 How likely is it that you will save money during the next 12 months?

- very likely

- quite likely

- unlikely

- very unlikely

- don't know

Question 13 Given the current economic situation, do you think it's a good time to save right now?

- yes, it's a good time

- probably yes

- not really

- not at all

- don't know 


\section{B. France}

Question 1 A votre avis, au cours des douze derniers mois, la situation économique générale de la France...

- s'est nettement améliorée

- s'est un peu améliorée

- est restée stationnaire

- s'est un peu dégradée

- s'est nettement dégradée

- ne sait pas

Question 2 A votre avis, au cours des douze prochains mois, la situation économique générale de la France...

- va nettement s'améliorer

- va un peu s'améliorer

- va rester stationnaire

- va un peu se dégrader

- va nettement se dégrader

- ne sait pas

Question 3 Pensez-vous que, dans les douze prochains mois, le nombre de chômeurs va ...

- fortement augmenter

- un peu augmenter

- rester stationnaire

- un peu diminuer

- fortement diminue

- ne sait pas

Question 4 Trouvez-vous que, au cours des douze derniers mois, les prix ont ...

- fortement augmenté

- moyennement augmenté

- un peu augmenté

- stagné

- diminué

- ne sait pas

Question 5 Par rapport aux douze derniers mois, quelle sera $\tilde{A}$ votre avis l'évolution des prix au cours des douze prochains mois?

- elle va être plus rapide

- elle va se poursuivre au même rythme

- elle va être moins rapide

- les prix vont rester stationnaires

- les prix vont diminuer

- ne sait pas 
Question 6 Dans la situation économique actuelle, pensez-vous que les gens aient intérêt à faire des achats importants? (meubles, machines à laver, matériels électroniques ou informatiques ...)

- oui, le moment est plutôt favorable

- le moment n'est ni favorable ni défavorable ...

- non, le moment est plut $\tilde{A}^{\prime} t$ défavorable

- ne sait pas

Question 7 Dans la situation économique actuelle, pensez-vous que ce soit le bon moment pour épargner?

- oui, certainement

- oui, peut-ètre

- non, probablement pas

- non, certainement pas

- ne sait pas

Question 8 A votre avis, au cours des douze derniers mois, le niveau de vie en France, dans l'ensemble s'est ...

- nettement amélioré

- un peu amélioré

- restée stationnaire

- un peu dégradé

- nettement dégradé

- ne sait pas

Question 9 A votre avis, au cours des douze prochains mois, le niveau de vie en France, dans l'ensemble va ...

- nettement s'améliorer

- s'améliorer un peu

- rester stationnaire

- se dégrader un peu

- nettement se dégrader

- ne sait pas

Question 10 Laquelle des affirmations suivantes vous semble décrire le mieux la situation financière actuelle de votre foyer?

- vous arrivez à mettre pas mal d'argent de còté

- vous arrivez à mettre un peu d'argent de còté

- vous bouclez juste votre budget

- vous tirez un peu sur vos réserves

- vous ètes en train de vous endetter

- ne sait pas

Question 11 Au cours des douze derniers mois, la situation financière de votre foyer s'est ... 
- nettement améliorée

- un peu améliorée

- restée stationnaire

- un peu dégradée

- un peu dégradée

- ne sait pas

Question 12 Pensez-vous que, au cours des douze prochains mois, la situation financière de votre Foyer va ...

- nettement s'améliorer

- un peu s'améliorer

- rester stationnaire

- un peu se dégrader

- nettement se dégrader

- ne sait pas

Question 13 Pensez-vous réussir à mettre de l'argent de côté au cours des douze prochains mois?

- oui, certainement

- oui, peut-être

- non, probablement pas

- non, certainement pas

- ne sait pas

Question 14 Au cours des douze prochains mois, par rapport aux douze mois passés, avez-vous l'intention de dépenser, pour effectuer des achats importants $\ldots$

- beaucoup plus

- un peu plus

- autant

- un peu moins

- beaucoup moins

- ne sait pas 


\section{Sweden}

Question 1 Hur ar ditt hushalls ekonomiska situation for narvarande jamfort med for 12 manader sedan? Ar den ...

- Mycket battre

- Nagot battre

- Ungefar lika

- Nagot samre

- Mycket samre

- Vet inte

Question 2 Hur tror du att ditt hushalls ekonomiska situation ar om 12 manader? Ar den ...

- Mycket battre

- Nagot battre

- Ungefar lika

- Nagot samre

- Mycket samre

- Vet inte

Question 3 Hur tycker du att den ekonomiska situationen ar $i$ Sverige for narvarande jamfort med for 12 manader sedan? Ar den ...

- Mycket battre

- Nagot battre

- Ungefar lika

- Nagot samre

- Mycket samre

- Vet inte

Question 4 Hur tror du att den ekonomiska situationen ar $i$ Sverige om 12 manader? Ar den...

- Mycket battre

- Nagot battre

- Ungefar lika

- Nagot samre

- Mycket samre

- Vet inte

Question 5 Jamfort med for 12 manader sedan, tycker du att priserna $i$ allmanhet for narvarande ar...

- Mycket hogre

- Ganska mycket hogre

- Nagot hogre

- Ungefar desamma

- Lagre 
- Vet inte

Question 6 Om du jamfor med dagens situation, tror du att priserna $i$ allmanhet om 12 manader kommer att ...

- Stiga snabbare

- Stiga i samma takt

- Stiga langsammare

- Vara i stort sett oforandrade

- Sjunka nagot

- Vet inte

Question 7 Hur tror du att arbetslosheten kommer att utvecklas under de narmaste 12 manaderna? Kommer den att ...

- Oka mycket

- Oka nagot

- Vara ungefar som nu

- Minska nagot

- Minska mycket

- Vet inte

Question 8 Har risken for att Du sjalv ska bli arbetslos under de senaste 12 manaderna ...?

- Oka mycket

- Oka nagot

- Vara ungefar som nu

- Minska nagot

- Minska mycket

- Vet inte

Question 9 Tycker du att det $i$ dagslaget ar fordelaktigt for folk $i$ allmanhet att gora stora inkop, som exempelvis mabler, tvattmaskiner, TV osv.?

- Ja, det ar ratt tidpunkt

- Varken ratt eller fel tidpunkt

- Nej, det ar fel tidpunkt, inkapet bar ske senare

- Vet inte

Question 10 Hur mycket pengar tror du att ditt hushall kommer att anvanda till inkop av sadana kapitalvaror under de narmaste 12 manaderna jamfort med de senaste 12 manaderna? Blir det ...

- Mycket mer

- Nagot mer

- Ungefar lika mycket

- Nagot mindre

- Mycket mindre

- Vet inte 
Question 11 Mot bakgrund av det allmanna ekonomiska laget, hur tycker du att det ar att spara for narvarande? Som sparande raknas aven minskning av eventuella lan. Ar det...

- Mycket fordelaktigt

- Ganska fordelaktigt

- Varken fordelaktigt eller ofordelaktigt

- Ganska ofordelaktigt

- Mycket ofordelaktigt

- Vet inte

Question 12 Hur troligt ar det att Ditt hushall kommer att kunna spara nagot under de narmaste 12 manaderna? Som sparande raknas aven minskning av eventuella lan. Ar det ...?

- Mycket troligt

- Ganska troligt

- Inte sarskilt troligt

- Inte alls troligt

- Vet inte

Question 13 Vilket av faljande pastaenden beskriver bast ditt hushalls nuvarande ekonomiska situation?

- Vi skuldsatter oss och/ eller utnyttjar sparade medel i stor utstrackning

- Vi skuldsatter oss och/ eller utnyttjar sparade medel

- Vi gar ungefar jamnt upp

- Vi sparar nagot

- Vi sparar mycket

- Vet inte 


\section{United Kingdom}

Question 1 How has the financial situation of your household changed over the last 12 months?

It has ...

- Got a lot better

- Got a little better

- Stayed the same

- Got a little worse

- Got a lot worse

- Don't Know

Question 2 How do you expect the financial position of your household to change over the next 12 months?

It will ...

- Get a lot better

- Get a little better

- Stay the same

- Get a little worse

- Get a lot worse

- Don’t Know

Question 3 How do you think the general economic situation in this country has changed over the past 12 months?

It has ...

- Got a lot better

- Got a little better

- Stayed the same

- Got a little worse

- Got a lot worse

- Don’t Know

Question 4 How do you expect the general economic situation in this country to develop over the next 12 months?

It will ...

- Get a lot better

- Get a little better

- Stay the same

- Get a little worse

- Get a lot worse

- Don't Know 
Question 5 How do you think consumer prices have developed over the last 12 months?

They have ...

- Risen a lot

- Risen moderately

- Risen slightly

- Stayed about the same

- Fallen

- Don’t Know

Question 6 In comparison with the past 12 months, how do you expect consumer prices will develop in the next 12 months?

They will ...

- Increase more rapidly

- Increase at the same rate

- Increase at a slower rate

- Stay about the same

- Fall

- Don't Know

Question 7 How do you expect the number of people unemployed in this country will change over the next 12 months?

The number will ...

- Increase sharply

- Increase slightly

- Remain the same

- Fall slightly

- Fall sharply

- Don't Know

Question 8 In view of the general economic situation, do you think now is the right time for people to make major purchases such as furniture or electrical goods?

- Yes, now is the right time

- It is neither the right time nor the wrong time

- No, it is the wrong time

- Don't Know

Question 9 Compared to the last 12 months, do you expect to spend more or less money on major purchases such as furniture and electrical goods?

I will spend ... 
- Much more

- A little more

- About the same

- A little less

- Much less

- Don't Know

Question 10 In view of the general economic situation, do you think that now is?

- A very good time to save

- A fairly good time to save

- Not a good time to save

- A very bad time to save

- Don’t Know

Question 11 Over the next 12 months, how likely will you be to save any money?

- Very likely

- Fairly likely

- Not likely

- Not at all likely

- Don't Know

Question 12 Which of these statements best describes the current financial situation of your household?

- We are saving a lot

- We are saving a little

- We are just managing to make ends meet on our income

- We are having to draw on our savings

- We are running into debt

- Don’t Know

\section{Data}

When conducting the survey, GfK also collects a rich set of demographics. We enlist the variables below, and report the possible values the variables obtained in the sample in parentheses.

Sex (male, female), age (continuous), household size $(1,2,3,4,5$ and more $)$, city size $(0 \leqslant$ size $\leqslant 1,999,2,000 \leqslant$ size $\leqslant 2,999,3,000 \leqslant$ size $\leqslant 4,999,5,000 \leqslant$ size $\leqslant 9,999$, $10,000 \leqslant$ size $\leqslant 19,999, \quad 20,000 \leqslant$ size $\leqslant 49,999, \quad 50,000 \leqslant$ size $\leqslant 99,999, \quad 100,000 \leqslant$ size $\leqslant 199,999$, $200,000 \leqslant$ size $\leqslant 499,999,500,000 \leqslant$ size), marital status (single, couple, married, widowed, divorced, separated), children at home (yes, no), number of children (1, 2, 3, 
4 and more), homeownership (house owner, apartment owner, renter), household head (yes, no), education (Hauptschule, Realschule, Gymnasium, University), employment (full-time, part-time, not employed), state (Schleswig-Holstein, Hamburg, Bremen, Berlin(West), Niedersachen, Nordrhein-Westfalen, Hessen, Rheinland-Pfalz, Saarland, Baden-Wuerttemberg, Bayern, Mecklenburg-Vorpommern, Sachsen-Anhalt, Brandenburg, Thueringen, Sachsen, Berlin(Ost)), monthly net income (inc) (inc $\leqslant 500$, $500<$ inc $\leqslant 750,750<$ inc $\leqslant 1,000,1,000<$ inc $\leqslant 1,2500,1,2500<$ inc $\leqslant 1,500,1,500<$ inc $\leqslant 2,000$, $2,000<$ inc $\leqslant 2,500,2,500<$ inc $\leqslant 3,000,3,000<$ inc $\leqslant 3,500,3,500<$ inc $\leqslant 4,000,4,000<$ inc $)$, job (farmer, liberal profession, self-employed, civil servant, white-collar worker, blue-collar worker, student, trainee, draftee, housewife, retiree, unemployed).

Data on the consumer price index, the unemployment rate, real durable consumption expenditure, real GDP, and industrial production are from the German Statistical Office (DeStatis); data on the European and German uncertainty index are from Baker et al. (2016); data on DAX and Volatility DAX are from the Deutsche Boerse; and oil price data are from Bloomberg.

We obtain the harmonized consumer price indexes (CPI) from the Statistical Data Warehouse at the European Central Bank. The data ID for the harmonized overall CPI is ICP.M.DE.N.000000.4.INX; for the all items CPI excluding food and energy it is ICP.M.DE.N.XEF000.4.INX; for the major durables CPI it is ICP.M.DE.N.0921_2.4.INX; and for the non-durable households goods CPI it is ICP.M.DE.N.056100.4.INX.

We obtain data for bank interest rates for loans to households in Germany for consumption from the Statistical Data Warehouse at the European Central Bank. The data ID is MIR.M.DE.B.A2B.A.R.A.2250.EUR.N. The rate is the annualized agreed rate, narrowly defined effective rate, for new loans for consumption excluding revolving loans and overdrafts, convenience and extended credit card debt.

Inflation expectations data for European Union member countries are from the European Commission Directorate on Economic and Financial Affairs.

Consensus forecasts of the one-year ahead the German consumer price inflation rate in percent at an annual rate are from Consensus Economics. The company surveys over 250 financial and economic professional forecasters for different macroeconomic variables such as future growth, inflation, interest rates, and exchange rates.

The ZEW Financial Market Experts Inflation Forecast Index is from the Center of 
European Economic Research (ZEW). ZEW Financial Market Survey is a monthly survey among 350 financial analysts and institutional investors in Germany. The survey asks participants about their six-month expectations concerning the economy, inflation rates, interest rates, stock markets, and exchange rates in Germany and other countries. The index is the difference between the fraction of surveyed financial experts which expect inflation to increase over the next six months minus the fraction of surveyed financial experts which expect inflation to decrease in percent.

The ECB Survey of Professional Forecasters (SPF) is a quarterly survey of expectations for the rates of inflation, real GDP growth, and unemployment in the euro area for several horizons. The participants to the Survey of Professional Forecasters are experts affiliated with financial or non-financial institutions based within the European Union.

\section{Press Clippings}

We briefly cite a few media quotes following the announcement of the newly-elected administration in 2005 to increase VAT by $3 \%$.

"Mehrwertsteuer ist glatter Betrug an den Waehler." Gruenen-Vorsitzende Claudia Roth haelt den Koalitionsvertrag fuer unsozial

"VAT is electoral fraud." Green party leader Claudia Roth calls coalition agreement antisocial

Berliner Morgenpost, 11/21/2005

Opposition kritisiert "Wahlbetrug." Vor allem hoehere Mehrwertsteuer stoesst auf Protest Opposition criticizes "electoral fraud." Especially higher VAT fiercely criticized

Frankfurter Rundschau, 11/14/2005

Opposition spricht von Wahlbetrug.

Opposition stresses "electoral fraud."

Die Welt, 11/13/2005

Die dreissten Steuerluegen.

Unapologetic tax lies. 
Westerwelle geisselt Steuererhoehungen.

Westerwelle criticizes tax hike.

Sueddeutsche Zeitung, 5/15/2006

Warum luegen Politiker?

Why do politician lie?

Welt am Sonntag, 5/14/2006

\section{Additional Results}

This section reports additional tests and robustness checks.

Figure A.5 plots the average treatment effect of the VAT increase on the readiness to buy durables, like Figure 9, but it also matches German and foreign households based on income expectations for the following twelve months in addition to gender, age group, education group, income group, and social status. The results are virtually identical.

Germany had negative residential property price inflation throughout our sample period and real GDP growth increased from $1.6 \%$ in the last quarter of 2005 to $4.38 \%$ in the last quarter of 2006.

Months and years dummies to control for seasonality and aggregate effects and shocks have little impact on our findings (see columns (1) and (2) of Table A.1). We might also interpret the answers to the survey questions as ordered options and estimate an ordered probit model. Even in this case, we estimate marginal effects in line with our baseline estimates (see column (3)). A linear probability model estimates consistent marginal effects (column (4)). In column (5), we add a set of dummies for all the elicited answers on inflation expectations instead of our single dummy for an expected inflation increase. The average marginal effect of "prices will increase more" rises to $10.5 \%$. Households that expect prices to rise more in the next twelve months compared to the previous twelve months are also on average $3 \%$ less likely to say that it is a bad time to purchase durables.

Households that expect inflation to increase are also more likely to answer that it is a bad time to save (see Table 6). 


\section{Figure A.1: Cyclical Readiness to Spend on Durables and Real Durable Consumption}

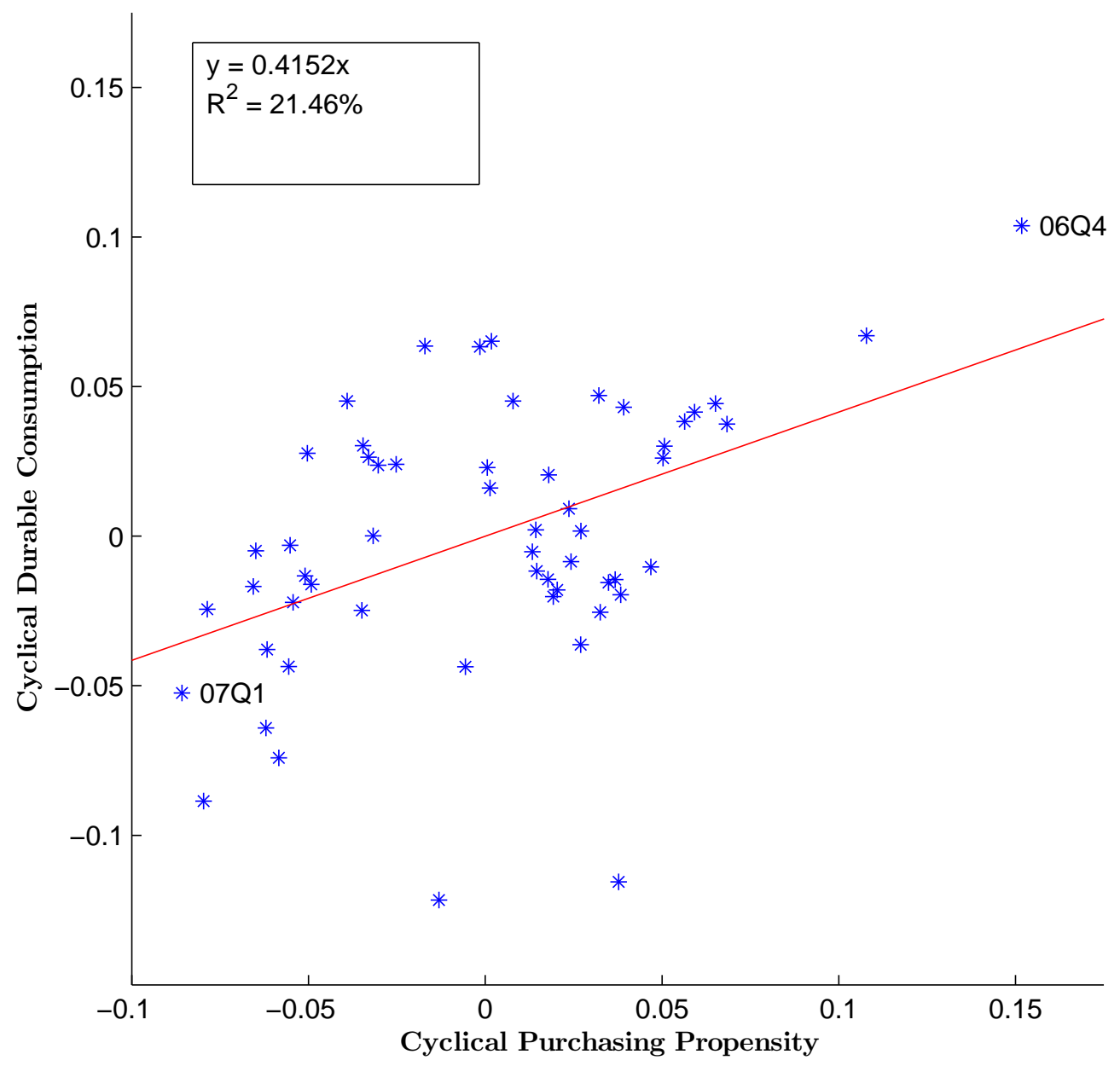

This figure is a scatter plot of the cyclical components of the average monthly readiness to purchase durables over time and of the natural logarithm of the real durable consumption at the quarterly frequency. We use a Hodrick-Prescott filter with smoothing parameter $\lambda=1,600$ to estimate the cyclical component. We use the confidential micro data underlying the GfK Consumer Climate MAXX survey to construct the readiness to purchase durables index. GfK asks a representative sample of 2,000 households whether it is a good time to purchase durables given the current economic conditions. Higher values correspond to better times. We use the end of quarter value to get a quarterly time series. The sample period is fist quarter 2000 to fourth quarter 2013 for a total of fourteen years. 
Figure A.2: Interest Rates for Consumption Loans

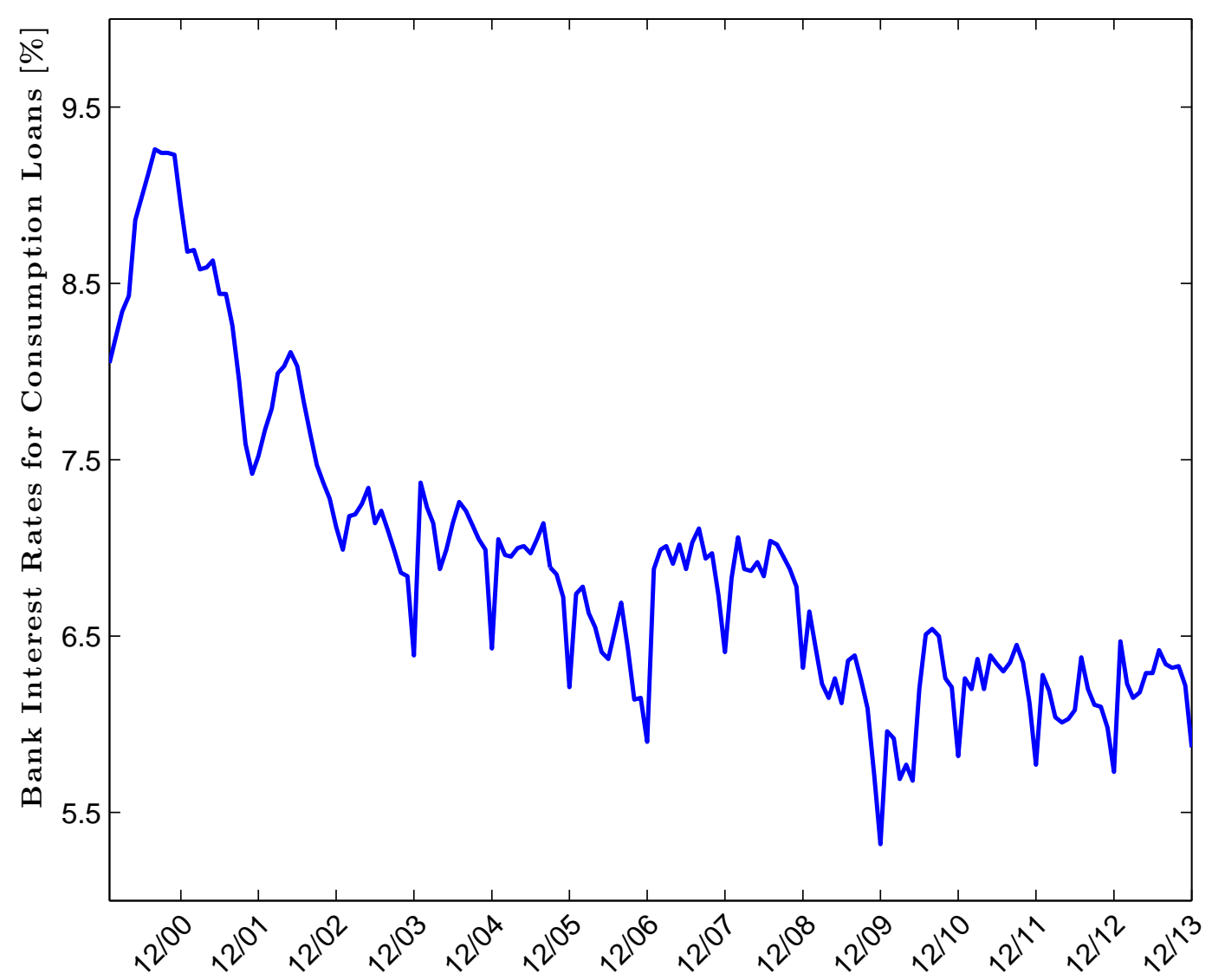

This figure plots the monthly time series of the bank interest rates for consumption loans to German households in percent at an annual rate. The sample period is first quarter 2000 to forth quarter 2013 for a total of fourteen years. 
Figure A.3: Residential Property Price Inflation Rate

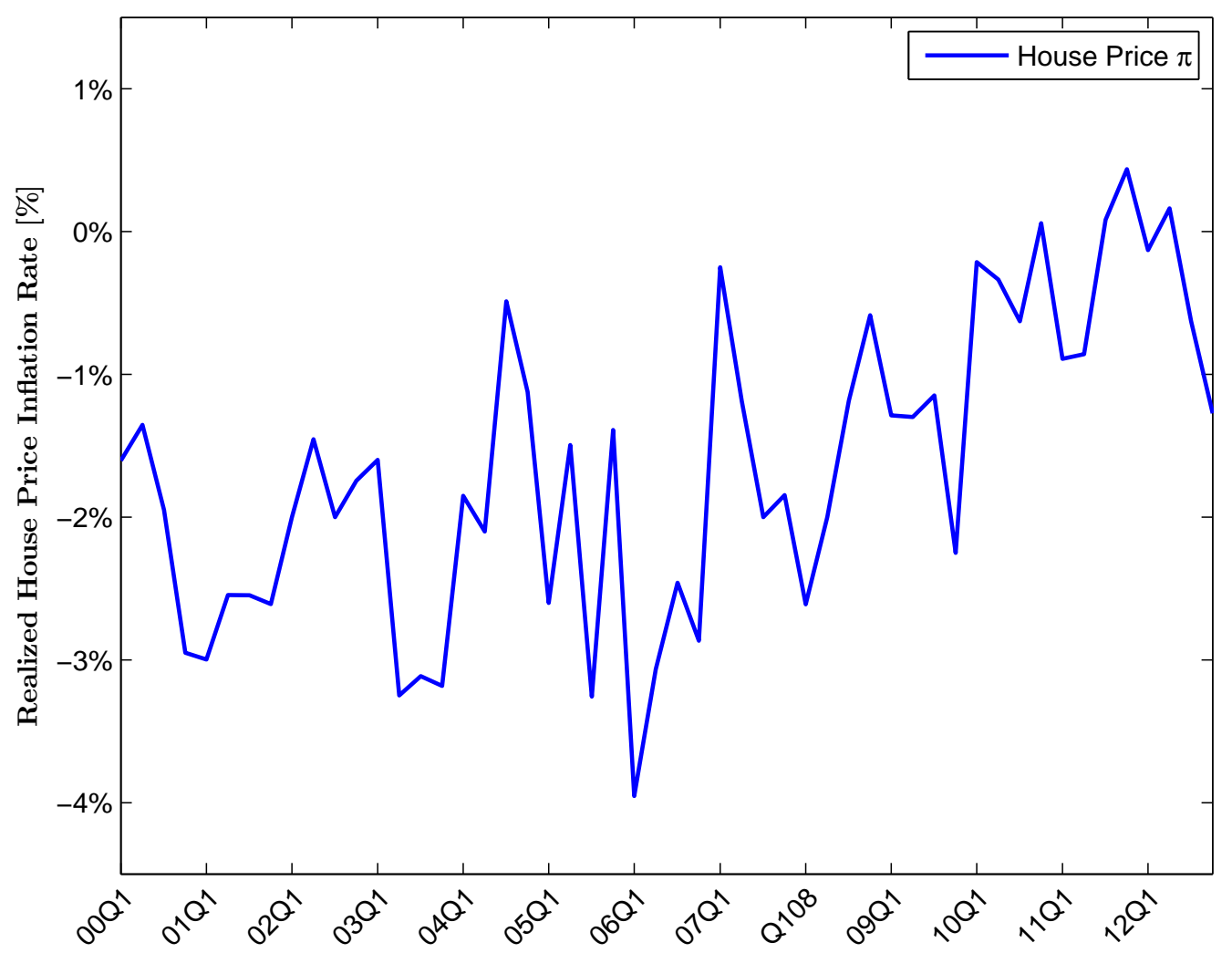

This figure plots the monthly time series of the German residential property price inflation rate in percent at an annual rate. The sample period is January 2000 to December 2013 for a total of fourteen years. 
Figure A.4: Policy Uncertainty
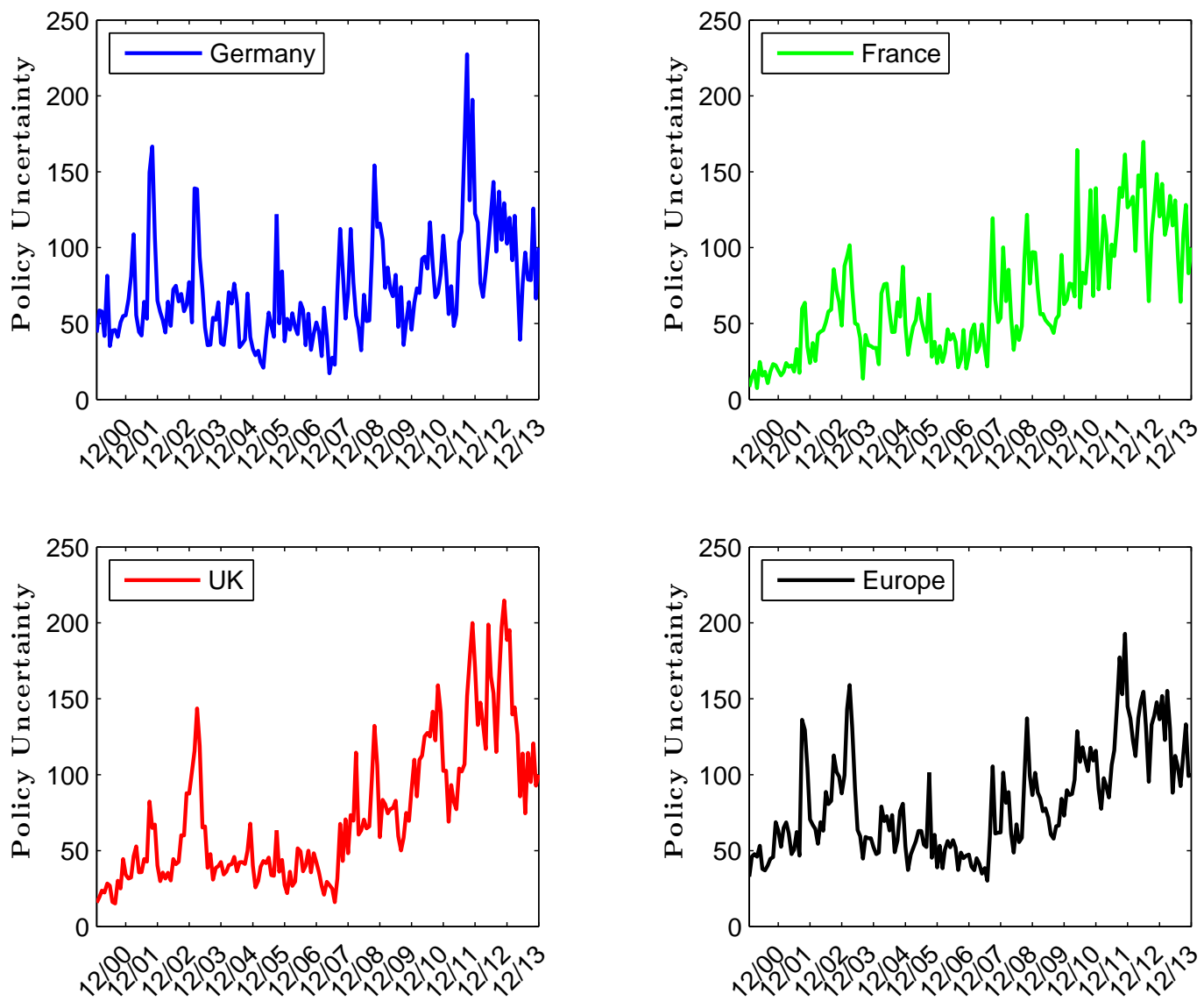

This figure plots the monthly policy uncertainty index of Baker, Bloom, and Davis (2016) over time. The sample period is January 2000 to December 2013 for a total of fourteen years. 
Figure A.5: Change in the Readiness to Spend on Durables for German vs. foreign households

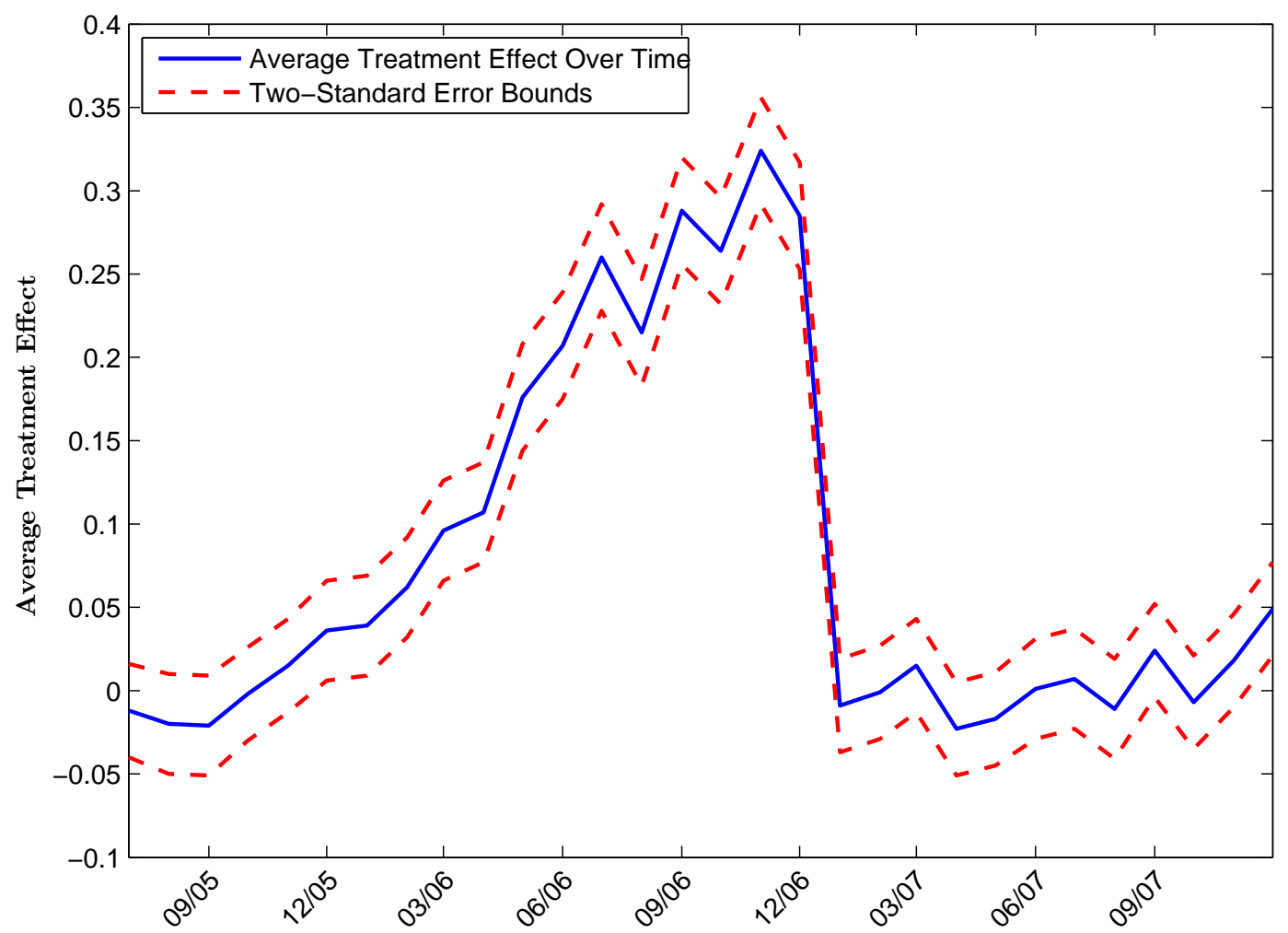

This figure plots the $\beta_{m}$ coefficient (solid line) of $\Delta D$ ur $r_{i, 06 / 2005 \rightarrow m}=\alpha+\beta_{m} \times V A T$ shock $k_{i}+\Delta X_{i, 06 / 2005 \rightarrow m}^{\prime} \times$ $\gamma+\epsilon_{i}$ and two standard deviation error bands (dashed line). $\Delta D u_{i, 06 / 2005 \rightarrow m}$ is the difference in the willingness to spend on durable goods between month $m$ and June 2005, VATshock $k_{i}$ is an indicator which equals 1 if the household was exposed to the VAT shock, $\beta_{m}$ captures the effect of the VAT shock on the willingness to buy durables for household $i$ in month $m$, and $\Delta X_{i, 06 / 2005 \rightarrow m}^{\prime}$ is the difference in a set of observables between month $m$ and the baseline month. We use the micro data underlying the DirectorateGeneral for Economic and Financial Affairs of the European Commission harmonized consumer surveys to construct these variables. 
Figure A.6: Readiness to Spend on Durables and Inflation Expectations Over Time

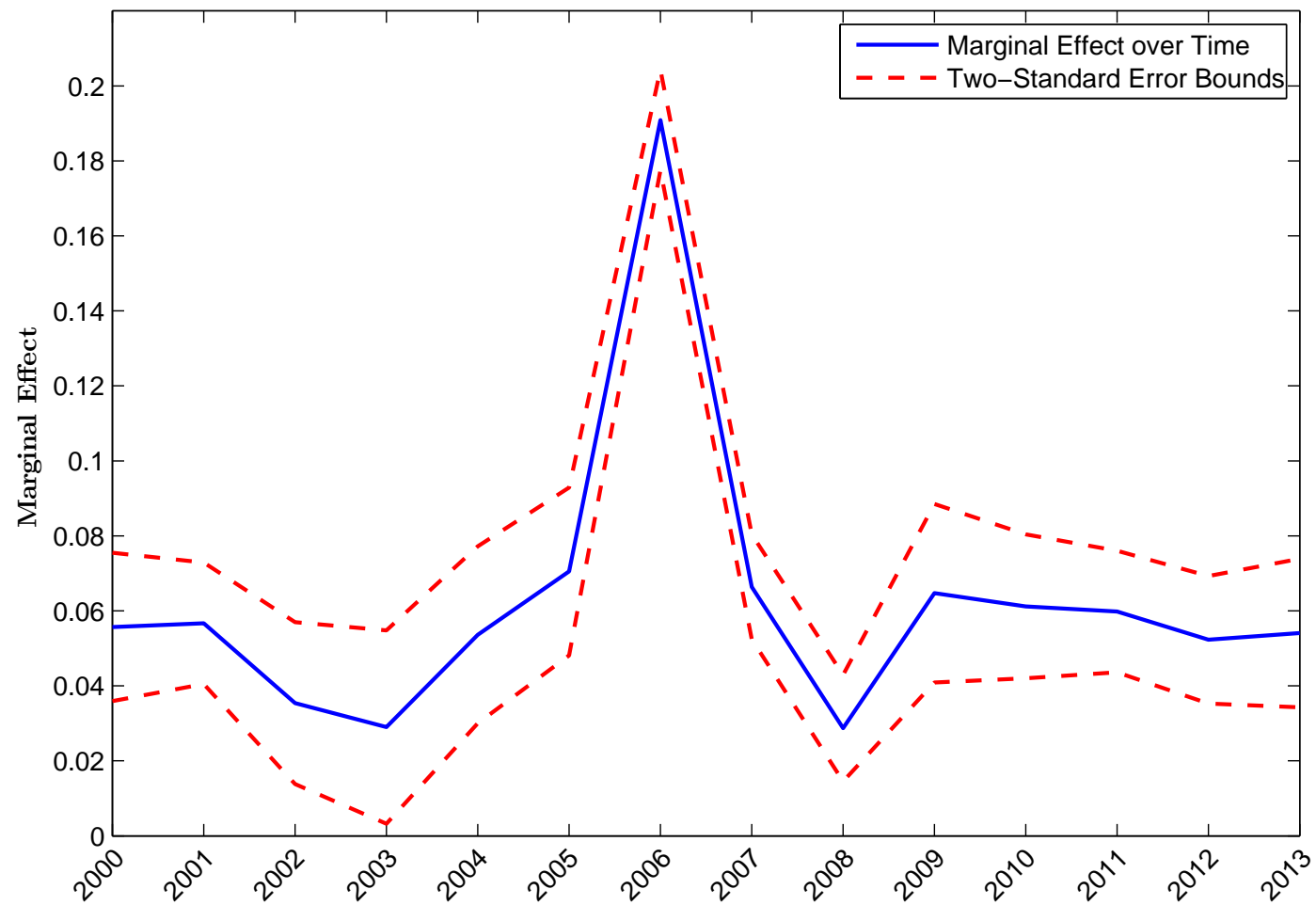

This figure plots the average marginal effect of inflation expectation on households' readiness to purchase durable goods of a multinomial logit regression over time and two standard deviation error bands. Inflation expectation is a dummy variable which equals 1 when a household replies that inflation will increase. The full set of covariates was added (see Table 2). We use the micro data underlying the GfK Consumer Climate MAXX survey to construct these variables. GfK asks a representative sample of 2,000 households on a monthly basis whether it is a good time to purchase durables given the current economic conditions. Households can reply that it is a good time, it is a bad time, or it is neither a good time nor a bad time. Standard errors are clustered at the quarter level. The sample period is January 2000 to December 2013 for a total of fourteen years. 


\section{Table A.1: Inflation Expectations and Readiness to Spend: month \& year dummies, ordered probit, OLS, inflation dummies}

This table reports the average marginal effects of multinomial logit, ordered probit, and OLS regressions for different time periods. Households' readiness to purchase durables is the dependent variable. Inflation expectation is a dummy variable which equals 1 when a household replies that inflation will increase. Past inflation measures the household perception of the increase in consumer prices during the last twelve months. We also control for household demographics and household expectations. We use the confidential micro data underlying the GfK Consumer Climate MAXX survey to construct these variables. GfK asks a representative sample of 2,000 households on a monthly basis whether it is a good time to purchase durables given the current economic conditions. Households can reply that it is a good time, it is a bad time, or it is neither a good time nor a bad time. Standard errors are clustered at the quarter level. The sample period is January 2000 to December 2013 for a total of fourteen years. Column (1) adds month fixed effects; column (2) adds year fixed effects; column (3) estimates an ordered probit specification; column (4) estimates an OLS specification; column (5) adds separate dummies for inflation categories.

\begin{tabular}{lccccc}
\hline & $\begin{array}{c}\text { Month } \\
\text { dummies } \\
(1)\end{array}$ & $\begin{array}{c}\text { Year } \\
\text { dummies } \\
(2)\end{array}$ & $\begin{array}{c}\text { Ordered } \\
\text { probit } \\
(3)\end{array}$ & $\begin{array}{c}\text { OLS } \\
(4)\end{array}$ & $\begin{array}{c}\text { Inflation } \\
\text { dummies } \\
(5)\end{array}$ \\
\hline Inflation expectation & $0.0878^{* * *}$ & $0.0719^{* * *}$ & $0.0479^{* * *}$ & $0.0988^{* * *}$ & \\
& $(0.0151)$ & $(0.0070)$ & $(0.0139)$ & $(0.0272)$ & \\
Prices will increase less & & & & & $0.0234^{* * *}$ \\
& & & & & $(0.0061)$ \\
Prices will increase the same & & & & & $0.0202^{* * *}$ \\
& & & & & $0.0073)$ \\
Prices will increase more & & & & & $0.1048^{* * *}$ \\
& & & & & \\
Past Inflation & $-0.0200^{* * *}$ & $-0.0096^{* * *}$ & $-0.0291^{* * *}$ & $-0.0598^{* * *}$ & $-0.0237^{* * *}$ \\
& $(0.0035)$ & $(0.0026)$ & $(0.0029)$ & $(0.0061)$ & $(0.0034)$ \\
\hline Demographics & & & & & $\mathrm{X}$ \\
Individual expectations & $\mathrm{X}$ & $\mathrm{X}$ & $\mathrm{X}$ & $\mathrm{X}$ & $\mathrm{X}$ \\
Pseudo_R-sqr & 0.0657 & 0.0819 & 0.0564 & 0.1056 & 0.0657 \\
Nobs & 219,799 & 219,799 & 219,799 & 219,799 & 215,579 \\
\hline
\end{tabular}

Standard errors in parentheses

$* p<0.10, * * p<0.05, * * * p<0.01$ 


\section{Table A.2: Inflation Expectations and Readiness to Spend: VAT Experiment}

This table reports the average marginal effects of a multinomial logit regression for different time periods. Households' readiness to purchase durables is the dependent variable. Inflation increase is a dummy variable which equals 1 when a household replies that inflation will increase. Past inflation measures the household perception of the increase in consumer prices during the last twelve months. We also control for household demographics and household expectations. We use the confidential micro data underlying the GfK Consumer Climate MAXX survey to construct these variables. GfK asks a representative sample of 2,000 households on a monthly basis whether it is a good time to purchase durables given the current economic conditions. Households can reply that it is a good time, it is a bad time, or it is neither a good time nor a bad time. Standard errors are clustered at the quarter level. The sample period is January 2000 to December 2013 for a total of fourteen years. Column (1) restricts the sample to 11/2005-12/2006 to study the effect of the unexpected VAT increase in 2007 which was announced in November 2005, column (2) excludes the period 11/2005-12/2006, and column (3) restricts the sample to 2010-2012 to study the effect of the European sovereign debt crisis.

\begin{tabular}{lccc} 
& $11 / 2005-12 / 2006$ & excluding $11 / 2005-12 / 2006$ & $2010-2012$ \\
\hline & Good time & Good time & Good time \\
& $(1)$ & $(2)$ & $(3)$ \\
\hline Inflation increase & $0.1909 * * *$ & $0.0547 * * *$ & $0.0576 * * *$ \\
& $(0.0067)$ & $(0.0031)$ & $(0.0052)$ \\
Past Inflation & $0.0206 * * *$ & $-0.0146 * * *$ & $-0.0129 * * *$ \\
& $(0.0033)$ & $(0.0021)$ & $(0.0043)$ \\
& & $\mathrm{X}$ & $\mathrm{X}$ \\
Demographics & $\mathrm{X}$ & $\mathrm{X}$ & 0.0466 \\
Individual expectations & $\mathrm{X}$ & 0.0676 & 48,982 \\
Pseudo R & 0.0631 & 200,322 & \\
Nobs & 19,477 & & $\mathrm{X}$ \\
\hline Standard & & &
\end{tabular}

Standard errors in parentheses

$* p<0.10, * * p<0.05, * * * p<0.01$ 


\section{Table A.3: Inflation Expectations and Readiness to Spend: Homeownership}

This table reports the average marginal effects of a multinomial logit regression by home ownership. Households' readiness to purchase durables is the dependent variable. Inflation increase is a dummy variable which equals 1 when a household replies that inflation will increase. Past inflation measures the household perception of the increase in consumer prices during the last twelve months. We also control for household demographics and household expectations. We use the confidential micro data underlying the GfK Consumer Climate MAXX survey to construct these variables. GfK asks a representative sample of 2,000 households on a monthly basis whether it is a good time to purchase durables given the current economic conditions. Households can reply that it is a good time, it is a bad time, or it is neither a good time nor a bad time. Standard errors are clustered at the quarter level. The sample period is January 2000 to December 2013 for a total of fourteen years. Column (1) restricts the sample to home owners, column (2) to apartment owners, and column (3) to renters.

\begin{tabular}{lccc} 
& House owner & Apartment owner & Renter \\
\hline & $\begin{array}{c}\text { Good time } \\
(1)\end{array}$ & $\begin{array}{c}\text { Good time } \\
(2)\end{array}$ & $\begin{array}{c}\text { Good time } \\
(3)\end{array}$ \\
\hline Inflation increase & $0.0834 * * *$ & $0.0766 * * *$ & $0.0938 * * *$ \\
& $(0.0173)$ & $(0.0191)$ & $(0.0156)$ \\
Past Inflation & $-0.0216 * * *$ & $-0.0228 * * *$ & $-0.0186 * * *$ \\
& $(0.0034)$ & $(0.0048)$ & $(0.0039)$ \\
& & & $\mathrm{X}$ \\
Demographics & $\mathrm{X}$ & $\mathrm{X}$ & $\mathrm{X}$ \\
Individual expectations & $\mathrm{X}$ & $\mathrm{X}$ & 0.0665 \\
Pseudo R & 0.0616 & 0.0607 & 116,137 \\
Nobs & 90,021 & 13,641 & \\
\hline
\end{tabular}

Standard errors in parentheses

$* p<0.10, * * p<0.05, * * * p<0.01$ 
Table A.4: Inflation Expectations and Readiness to Spend: Employment

This table reports the average marginal effects of a multinomial logit regression by employment status. Households' readiness to purchase durables is the dependent variable. Inflation increase is a dummy variable which equals 1 when a household replies that inflation will increase. Past inflation measures the household perception of the increase in consumer prices during the last twelve months. We also control for household demographics and household expectations. We use the confidential micro data underlying the GfK Consumer Climate MAXX survey to construct these variables. GfK asks a representative sample of 2,000 households on a monthly basis whether it is a good time to purchase durables given the current economic conditions. Households can reply that it is a good time, it is a bad time, or it is neither a good time nor a bad time. Standard errors are clustered at the quarter level. The sample period is January 2000 to December 2013 for a total of fourteen years. Columns (1) and (2) restrict the sample to full-time employed respondents, columns (3) and (4) to part-time employed respondents, and columns (5) and (6) to unemployed respondents.

\begin{tabular}{|c|c|c|c|c|c|c|}
\hline & \multicolumn{2}{|c|}{ Full-time Employment } & \multicolumn{2}{|c|}{ Part-time Employment } & \multicolumn{2}{|c|}{ Not Employed } \\
\hline & $\begin{array}{c}\text { Bad time } \\
(1)\end{array}$ & $\begin{array}{c}\text { Good time } \\
(2)\end{array}$ & $\begin{array}{c}\text { Bad time } \\
(3)\end{array}$ & $\begin{array}{c}\text { Good time } \\
(4)\end{array}$ & $\begin{array}{c}\text { Bad time } \\
(5)\end{array}$ & $\begin{array}{c}\text { Good time } \\
(6)\end{array}$ \\
\hline Inflation increase & $\begin{array}{r}-0.0051 \\
(0.0080)\end{array}$ & $\begin{array}{l}0.0923 * * * \\
(0.0169)\end{array}$ & $\begin{array}{c}-0.0072 \\
(0.0100)\end{array}$ & $\begin{array}{l}0.0845 * * * \\
(0.0186)\end{array}$ & $\begin{array}{r}-0.0103 \\
(0.0098)\end{array}$ & $\begin{array}{l}0.0852 * * * \\
(0.0149)\end{array}$ \\
\hline Past Inflation & $\begin{array}{l}0.0345 * * * \\
(0.0034)\end{array}$ & $\begin{array}{c}-0.0202 * * * \\
(0.0038)\end{array}$ & $\begin{array}{l}0.0355 * * * \\
(0.0034)\end{array}$ & $\begin{array}{c}-0.0209 * * * \\
(0.0042)\end{array}$ & $\begin{array}{l}0.0413 * * * \\
(0.0035)\end{array}$ & $\begin{array}{c}-0.0203 * * * \\
(0.0035)\end{array}$ \\
\hline Demographics & $\mathrm{X}$ & $\mathrm{X}$ & $\mathrm{X}$ & $\mathrm{X}$ & $\mathrm{X}$ & $\mathrm{X}$ \\
\hline Individual expectations & $\mathrm{X}$ & $\mathrm{X}$ & $\mathrm{X}$ & $\mathrm{X}$ & $\mathrm{X}$ & $\mathrm{X}$ \\
\hline Pseudo $\mathrm{R}^{2}$ & \multicolumn{2}{|c|}{0.0655} & \multicolumn{2}{|c|}{0.0623} & \multicolumn{2}{|c|}{0.0617} \\
\hline Nobs & \multicolumn{2}{|c|}{96,555} & \multicolumn{2}{|c|}{30,238} & \multicolumn{2}{|c|}{93,006} \\
\hline
\end{tabular}

Standard errors in parentheses

$* p<0.10, * * p<0.05, * * * p<0.01$ 


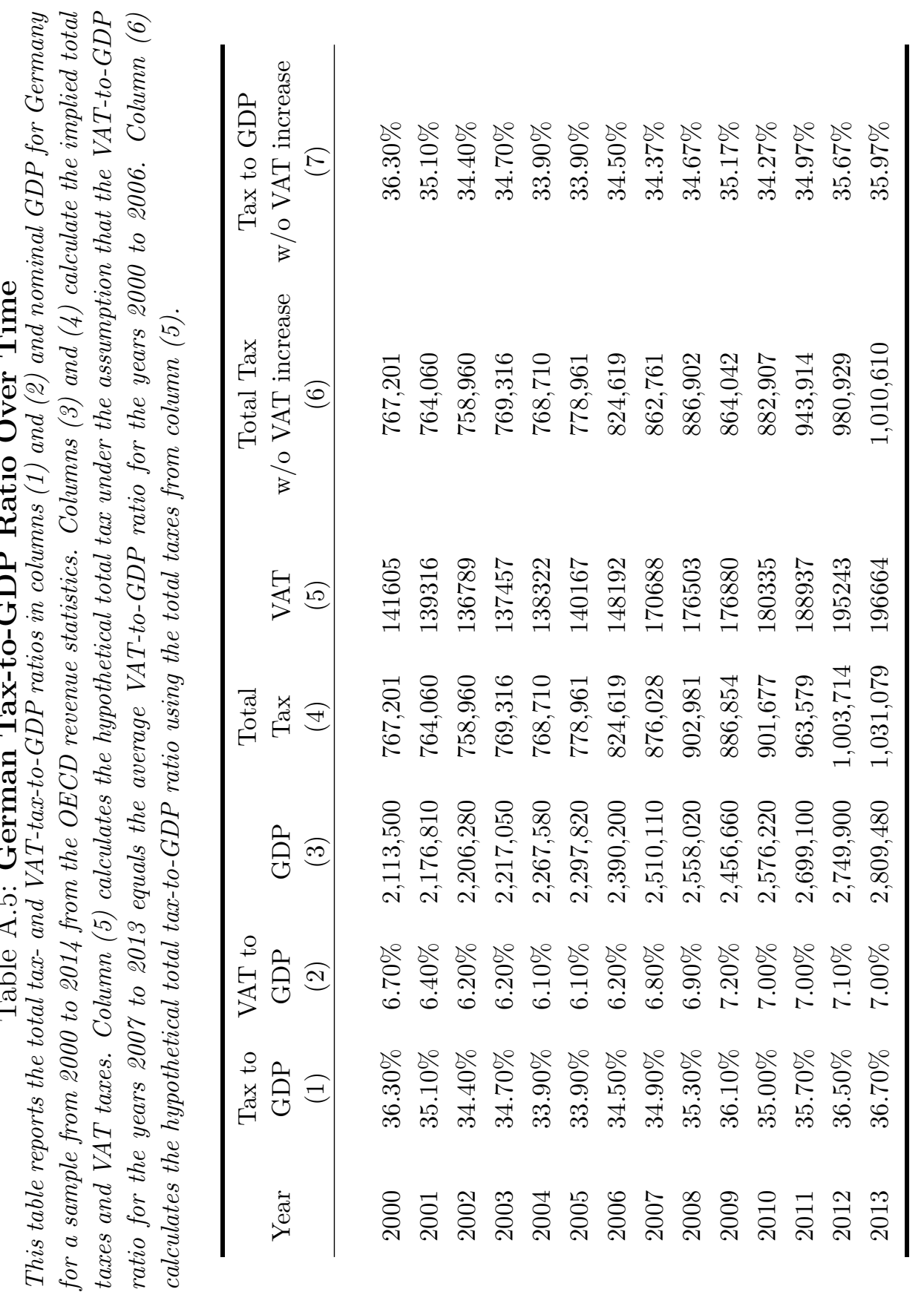




\section{Working Paper Series in Economics}

recent issues

No.94 Francesco D'Acunto, Daniel Hoang and Michael Weber: The effect of unconventional fiscal policy on consumption expenditure, October 2016

No. 93 Andranik S. Tangian: The third vote experiment: VAA-based election to enhance policy representation of the KIT student parliament, September 2016

No. 92 Clemens Puppe and Arkadii Slinko: Condorcet domains, median graphs and the single-crossing property, June 2016

No. 91 Markus Höchstötter, Mher Safarian, Anna Krumetsadik: Analysis of stochastic technical trading algorithms, June 2016

No. 90 Nikolaus Schweizer and Nora Szech: Optimal revelation of life-changing information, May 2016

No. 89 Helena Barnard, Robin Cowan, Alan Kirman and Moritz Müller: Including excluded groups: The slow racial transformation of the South African university system, May 2016

No. 88 Aniol Llorente-Saguer, Roman M. Sheremeta and Nora Szech: Designing contests between heterogeneous contestants: An experimental study of tie-breaks and bid-caps in all-pay auctions, May 2016

No. 87 Johannes Karl Herrmann and Ivan Savin: Optimal policy Identification: Insights from the German electricity market, March 2016

No. 86 Andranik Tangian: Devaluation of one's labor in labor-commoditiesmoney-commodities-labor exchange as a cause of inequality growth, February 2016

No. 85 Thomas Deckers, Armin Falk, Fabian Kosse and Nora Szech: Homo moralis: Personal characteristics, institutions, and moral decision-making, February 2016

No. 84 Markus Fels: When the affordable has no value, and the valuable is unaffordable: The U.S. market for long-term care insurance and the role of Medicaid, February 2016

The responsibility for the contents of the working papers rests with the author, not the Institute. Since working papers are of a preliminary nature, it may be useful to contact the author of a particular working paper about results or caveats before referring to, or quoting, a paper. Any comments on working papers should be sent directly to the author. 